\title{
13- Kendi kendine Türkçe öğrenme kitaplarında telaffuz öğretimi
}

\section{Elif ERMAĞAN}

APA: Ermağan, E. (2021). Kendi kendine Türkçe öğrenme kitaplarında telaffuz öğretimi. RumeliDE Dil ve Edebiyat Araştırmaları Dergisi, (Ö10), 214-237. DOI: 10.29000/rumelide.1011393.

$\ddot{\mathbf{O} z}$

Dil öğretiminde konuşmayı etkili kılan ögelerin başında telaffuzun açık, anlaşılır olması gelmektedir. Buna karşın telaffuz öğretimi alanyazında geride bırakılan, görmezden gelinen, ihmal edilen tanımlarıyla karşımıza çıkmaktadır. Telaffuz çok bilinmeyenli bir denklem gibidir. Öğrenicinin ana dili, bireysel özellikleri, öğretmen yeterlikleri, hedef dilin öğretiminde kullanılan materyallerin etkisi, çözülmeyi bekleyen bu çok bilinmeyenli denklemi oluşturur. Telaffuzun, materyal tasarımcıları ve yabancı dil olarak Türkçe öğretimi kitap yazarları tarafından genel olarak işlevsel ve özgün işlenmeyişinden dolayı öğrenicinin bu konudaki gelişimine olumsuz etki ettiği düşünülmektedir. Bu çalışmada sözü edilen problemlerden yola çılılarak 20. yüzyılda çeşitli hedef kitlelerine yönelik Türkçe-İngilizce olarak yazılmış kendi kendine dil öğretmeyi amaçlayan yabancı veya Türk yazarların ortaya koyduğu on kitapta telaffuz öğretimine yer verilip verilmediği, yer verildiyse nasıl bir yol izlendiği incelenmiştir. Elde edilen bulgulardan hareketle kendi kendine dil öğretim kitaplarında telaffuz öğretiminin nasıl olabileceğine dair alternatifler geliştirmek hedeflenmiştir. İncelenen dil öğretim kitaplarının seçilme sebebi, bu kitapların daha çok konuşma becerisini kazandırmaya yönelik hazırlanması ve dolayısıyla telaffuz eğitiminin önemli bir yer tutması gerektiği düşüncesidir. Çalışmada, yöntem olarak betimsel tarama kullanılmış, literatür taraması ve doküman incelemesi yaklaşımıyla veriler analiz edilmiştir. Sonuç olarak, incelenen kitapların büyük çoğunluğunda Türkçedeki seslerin İngilizceyle karşılaştırmalı olarak incelendiği, telaffuz öğretiminin bazı kitaplarda Türkçenin telaffuzunda etkili olan ögeler dikkate alınarak yapılırken, bazılarında sınırlı bilgi verilerek işlendiği tespit edilmiştir.

Anahtar kelimeler: İki dilli kitaplar, kendi kendine dil öğrenme, konuşma becerisi, telaffuz

\section{Teaching pronunciation in self-learning Turkish books}

\begin{abstract}
One of the elements that make speaking effective in language teaching is that the pronunciation should be clear and understandable. On the other hand, pronunciation teaching comes up with definitions that are left behind, ignored and neglected in the literature. Pronunciation is like an equation with many unknowns. The learner's mother tongue, individual characteristics, teacher competencies, the effect of the materials used in teaching the target language form this multiunknown equation waiting to be solved. It is thought that the pronunciation has a negative impact on the development of the learner in this subject due to the fact that it is not generally functional and original by the material designers and the authors of teaching Turkish as a foreign language. Based on the problems mentioned in this study, it has been examined whether or not pronunciation teaching is included in the books, and if so, what kind of way is followed in the ten books put forward
\end{abstract}

Öğr. Gör. Dr., İstanbul Medeniyet Üniversitesi, TÖMER (İstanbul, Türkiye), elifermagan2020@gmail.com, ORCID ID: oooo-0002-2827-0155 [Araştırma makalesi, Makale kayt tarihi: 25.09.2021-kabul tarihi: 20.10.2021; DOI: 10.29000/rumelide.1011393]

Adres
RumeliDE Dil ve Edebiyat Araştırmaları Dergisi Osmanağa Mahallesi, Mürver Çiçeği Sokak, No:14/8 Kadıköy - ISTANBUL / TÜRKIYE 34714 e-posta: editor@rumelide.com tel: +90 505 7958124, +90 2167730616
Address

RumeliDE Journal of Language and Literature Studies Osmanağa Mahallesi, Mürver Çiçeği Sokak, No:14/8

Kadıköy - ISTANBUL / TURKEY 34714

e-mail: editor@rumelide.com

phone: +90 505 7958124, +90 2167730616 
by foreign or Turkish authors aiming to teach a language by themselves, written in Turkish-English for various target groups in the 2oth century. Based on the findings, it is aimed to develop alternatives about how to teach pronunciation in self-directed language teaching books. The reason for choosing the language teaching books examined is that these books should be prepared to gain more speaking skills and therefore pronunciation education should have an important place. In the study, data were analyzed with literature review and document review approach, using descriptive scanning as a method. As a result, it has been determined that in the majority of the books examined, the sounds in Turkish are examined in comparison with English, while the pronunciation teaching is done by taking into account the elements that are effective in the pronunciation of Turkish in some books, while in some books it is processed by giving limited information.

Keywords: Bilingual books, self-learning, speaking skills, pronunciation

\section{Giriş}

Konuşma, dilin görünen, dışa açılan kısmıdır. Konuşmanın görünürlüğünü netleştiren ise konuşma becerisidir. Konuşma becerisinin elde edilmesi bireyin özelliklerinden öğretmenin tutumuna veya kullanılan materyallere değin birçok bileşeni kapsamaktadır.

Sınıf içi öğrenme ortamında öğrenicinin konuşması, gerek akran gerekse öğretmen tarafından değerlendirilme imkânı bulurken, sınıf dışı öğrenme ortamlarında hedef dili öğrenen öğreniciler için bu durum kendi bireysel çabalarıla ve seçtikleri materyallerle gerçekleşmektedir.

Bir denetleyici ve değerlendiriciden yoksun kalınan bu öğrenme ortamında öğrenici kendisinin öğretmenidir. Öğrenici kendi öğrenme sürecini, ihtiyaçları doğrultusunda seçtiği materyallere göre planlayarak tüm sorumluluğu üstüne alır. Kendi kendine öğrenme olarak adlandırılan bu öğrenme biçiminde baş materyal kitaplardır. Kendi kendine dil öğrenme kitapları olarak tanımlanan bu kitaplar özellikle internetin varlığının ortaya çıkmadığı, teknolojinin henüz günümüzdeki gibi uygulanmadığı dönemlerde dil öğrenme gereksinimini karşılamıştır.

Daha çok, günlük iletişim ihtiyaçlarını destekler nitelikte dilbilgisi konularının temel seviyede tutularak daha çok konuşma becerisini desteklemeye yönelik hazırlanan bu kitaplarda, konuşmanın başat ögelerinden olan telaffuzun ne kadar yer tuttuğu ve öğrenme sürecine nasıl dâhil edildiği kayda değer bir yer tutmaktadır. Ders kitaplarında kullanılan telaffuz bölümlerinin uygulanışında öğretmen tarafından öğrenicinin yaptığı telaffuz hataları alışkanlık hâline gelmemesi için dönütlerle düzeltilirken, kendi kendine dil öğrenme kitaplarında bu durum mevcut olmayıp öğrenicinin kendi değerlendirilmesine birakılmıştır.

\section{Telaffuz öğretiminde etkili olan ögeler}

Telaffuz, alanyazında söyleyiş, sesletim, sesleme ve boğumlanma gibi farklı terimlerle ve aşağıdaki tanımlarla karşımıza çıkmaktadır. Türk Dil Kurumuna göre boğumlanma başlı̆̆ı altında, "Ciğerlerden gelen havanın, ağız ve burundaki çeşitli nokta ve bölgelerde engellemeye uğrayarak ses olarak çıkması, telaffuz, artikülasyon.” olarak ifade edilmektedir (TDK). Özgür, TDK’nın tanımını genişletip, telaffuzda etkili olan konuşma araç ve yollarını da açıkça belirtip "Nefesin gırtlaktan çıktıktan sonra yutak, ağız ve burundan oluşan üçüncü küme organlarında (dil, diş, damakta) konuşma dilimizin geleneksel seslerine dönüşüp biçimlenmesidir" şeklinde açıklamaktadır (Özgür, 2006: 17). Çakır ise kısaca "Sözcükleri oluşturan seslerin düzgün ve açık bir şekilde sesletilmesidir" olarak tanımlarken (Çakır, 2015: 221),

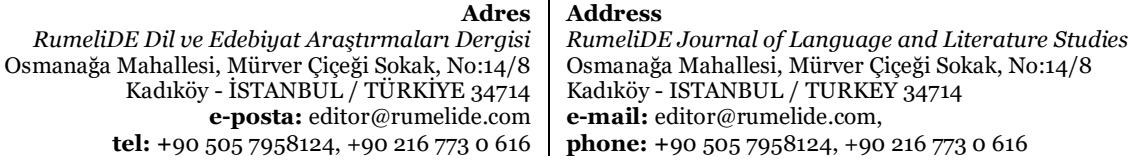


Karaca ise Çakır'la, neredeyse birebir aynı tanımı yaparak "Kelimeleri oluşturan seslerin ağızdan doğru ve anlaşılır bir şekilde çıkarılmasıdır” şeklinde ifade etmektedir (Karaca, 2019: 37).

Tüm bu tanımlar incelendiğinde, telaffuzu, çeşitli konuşma araçlarının yardımıyla seslerin doğru, açlk ve anlaşılır bir şekilde o dile ait tonlama, vurgu, jest, mimikler gibi ögelere bağlı kalınarak zamanlama ve ses kalitesinin yardımıyla çıkarılması şeklinde tanımlamak mümkündür.

Genel olarak diğer becerilerden önde tutulan, dili bilme ölçütü olarak kabul edilen konuşma becerisi yabancı dil olarak Türkçe öğretimindeki yeri açısından değerlendirildiğinde beklenen değerin verilmediği görülmektedir. Potur ve Yıldız, konuşma becerisinin diğer dil becerileri ile karşılaştırıldığında en fazla ihmal edilen ve üzerine en az çalışma yapılan beceri olduğunu saptamaktadır (Potur ve Yıldız, 2016: 29). Keser de Potur ve Yıldız’n görüşlerini destekler nitelikte yabancı dil olarak Türkçe öğretimi alanında da konuşma becerisi üzerine yapılmış çalışmaların sayıca az ve konu çeşitliliği bakımından sınırlı olduğunu belirtmektedir (Keser, 2018: 1-2). Bununla ilintili olarak konuşma becerisinin alt ögelerinden olan telaffuz öğretimi konusu da alanyazında yeterli ilgiyi görmediğinden yapılan çalışmalarda göz ardı edilen, geride bırakılan, görmezden gelinen tanımlarıyla karşılanmıştır. Hâlbuki bir dilde konuşma becerisinin öğrenimine giden yolun anlaşılırlığını büyük oranda etkileyen konuşma becerisinin alt becerilerinden sayılan ve becerinin ölçülmesinde ölçüt olarak alınan telaffuzdur. Hedge'ye (2000) göre yabancı dili yeterli düzeyde konuşma üzerinde birçok etken vardır ve bunlardan biri de sesleri doğru ve anlaşlır bir biçimde sesletmektir (akt. Özmen ve diğerleri, 2017: 602). Bodorik de telaffuzun anlaşlırlıkta önemli bir rol üstlendiğini ifade ederken (Bodorik, 2017: 158), Aslan da Bodorik'le benzer şekilde dil öğretiminin en önemli konularından biri olan telaffuzun anlaşlır bir iletişim için son derece önemli olduğunu belirtir (Aslan, 2015: 197).

Yukarıda da belirtildiği gibi sağlıklı bir iletişimde konuşma becerisinin edinilmesinin anahtarı olarak nitelendirilebilecek anlaşılır telaffuzun, öğretmen ve öğrenici tarafından uygulanmasında materyaller rehberlik etmektedir. Daha çok konuşma becerisi kazandırma amaçl, bir konuşma kılavuzu niteliğinde olan bu kitaplarda telaffuz kısımlarının üzerinde özenle durulması gerektiği düşünülmektedir. Bu noktada, öğrenicinin kendi kendine dili öğrenmesinde önemli materyallerden sayllan kendi kendine Türkçe öğrenme kitaplarında telaffuzun öğretimini etkili kılan kitap yazarının ya da komisyonca tercih edilen dil öğretim yöntemi, telaffuz öğretme teknikleriyle birlikte kitabın hedef kitlesi ve yazılış amacının kazandırılmak istenen beceriler dolayısıyla telaffuz ögesi üzerinde etkili olduğu düşünülmektedir.

Yöntem, hangi beceriye öncelik verileceğini ve bu becerilerin telaffuzla ilişkisini belirlemektedir. Çalışma için örnekleme alınan kitaplar incelendiğinde ise kitapların işitsel-dilsel yöntem, dilbilgisi çeviri yöntemi, doğal yöntem ve iletişim yaklaşımla yazıldığı tespit edilmiştir.

$\mathrm{Bu}$ yöntemler, telaffuz ilişkisi bağlamında değerlendirildiğinde işitsel-dilsel yöntem dinleme ve konuşma becerilerine öncelik veren yöntem olduğu için tekrara dayalı telaffuz alıştırmaları ön plandadır. Davranışçı psikologlar ve yapısal dilbilimcilerin görüşleri etrafında şekillenen bu yöntem, dinleme ve konuşma becerilerine öncelik vererek dildeki kalıp yapıları öğreterek yabancı dilin edinilebileceğini savunur (Bölükbaş, 2018: 61). Celce-Murcia’nın (2006) ifade ettiği gibi ayrıca öğretmen bu yöntemde ek olarak seslerin telaffuzunu gösteren çizelgeler ya da görsel transkripsiyon sistemi (uluslararası fonetik alfabesi) gibi fonetik araçları da telaffuz öğretiminde kullanır (akt: Toraman Ünal, 2020: 23). Bunun dışında bu yöntemde kullanılan ders kitabına yardımcı olarak kaset kullanılarak öğretilmek istenen kelime, kalıp ifade ve diyaloglar dinlettirilerek, taklit ettirilip ezberletilir.

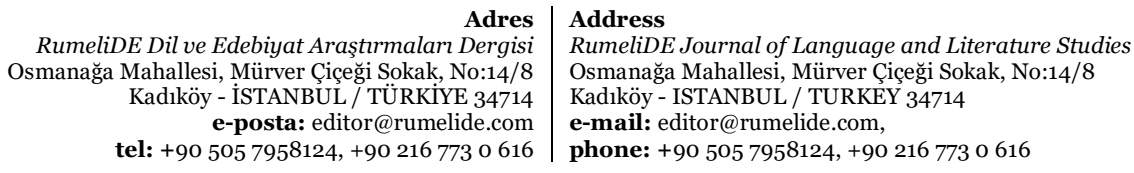


Kitaplarda tercih edilen bir diğer yöntem de telaffuzun geri planda kalıp, telaffuz alıştırmalarına neredeyse hiç yer verilmeyen dilbilgisi-çeviri yöntemidir. Bu yöntemde "Telaffuz pek fazla önem taşımaz. Telaffuza hiç dikkat edilmez ya da çok az dikkat edilir. Yani söyleyiş alıştırmalarına hemen hemen hiç yer verilmez." (Demirel, 2012: 36-37). Bu nedenle bu yöntemin uygulandığı ders kitabı ve öğretim programlarında, konuşma becerisinde telaffuz öğretiminde aksaklıklar görülmesi muhtemeldir.

Dinleme ve konuşmanın işitsel-dilsel yöntemde olduğu gibi ön planda tutulduğu, dilbilgisi-çeviri yönteminin tersine okuma ve yazmanın geride planda kaldığı eleştirilerinin yapıldığı doğal yöntem de incelenen kitaplarda yer alan yöntemlerden biridir. Memiş ve Erdem de, "doğal yöntemle yabancı dil öğrenen öğrenciler özellikle günlük dili konuşmakta ve öğrendikleri sözcükleri doğru telaffuz etmekte başarılı olmalarına rağmen okuma ve yazma becerileri yönünden yetersiz kalmaktadırlar." demektedir (Memiş ve Erdem, 2013: 303). İşitsel-yöntemde olduğu gibi taklit ve tekrar üzerinde durulmasının nedeni doğru telaffuzun önem taşımasıdır.

Kitaplar incelendiğinde bu üç yöntemin dışında iletişimsel yaklaşımın da kullanıldığı tespit edilmiştir. Demir, "20.yüzyılın ikinci yarısında ortaya atılan, bütün dil becerilerinin gelişimine aynı derecede önem vermeye dayalı, günümüzde yaygın olarak kullanılan iletişimci-faydacı yaklaşımın temel ilkelerine göre konuşma becerisi başlangıçta sözlü tekrar, günlük hayattan basit diyaloglar, soru-cevaplar ve gittikçe özgün konuşmaya yönlendiren alıştırmalarla geliştirilmelidir.” şeklinde fikir beyan etmektedir (Demir, 2013: 123).

Dil öğretim yöntemleri kadar önemli olan bir diğer alt başlık, telaffuz öğretim teknikleridir. Bu teknikler, dinle ve taklit et, alfabe öğretimi ya da daha geniş bir şekilde genellikle kitapların giriş kısımlarında yer verilen fonetik eğitim, görsel ögelerden yararlanma ya da yazılı örnekler ve uyarılardan oluşurken, sesli okuma etkinlikleri de konuşma ağırlıklı kitaplarda geçen diyalogların ses kayıtlarından dinlenerek taklit edilmesi yoluyla gerçekleşmektedir.

Kendi kendine dil öğrenme kitaplarındaki telaffuz ögesini incelemede yöntem ve tekniğin seçimini belirleyen unsurlardan ikisi de hedef kitle ve hedef kitlenin ihtiyacını kapsayan kitabın yazılış hedefidir. Türkçe öğrenmek isteyen hedef kitlelerin uyrukları, ana dilleri, lehçeleri, yaşları, öğrenme stilleri, amaçları, görevleri; onlarla ilgili olarak hazırlanan kitaplar (ders kitapları, konuşma kılavuzları, sözlükler), eğitsel materyaller, eğitim öğretim sırasında uygulanacak yöntem ve teknikler, başarıyı önemli ölçüde etkilemektedir (Alyılmaz, 2010: 728-749). Hedef kitlenin ana dili ya da bildiği diller açısından temel alınarak yazılan iki dilli kitaplar, telaffuz öğretiminin karşılaştırmalı olarak kaynak dil üzerinden yapılabilmesi açısından değerlidir. Kendi kendine dil öğrenme kitapları hedef kitlenin ana dili veya bir ara dil kullanılarak yabancı dil olarak Türkçe öğretimine yönelik olarak hazırlanmalıdır (Özbal, 2020: 1607). Ders kitabının amacını belirlemek ise öğrenici için öğrenmeyi planlama, dolayısıyla öğrenicinin öğrenme gereksinimlerini belirlemektir. Telaffuzla ilintili değerlendirildiğinde ise hedef kitleye bağlı olarak yazılan kitap, seçilecek yöntem, tekniği ve bu yöntem ve teknikle öne çıarılmak istenen beceriyle beraber telaffuza ne kadar ağırlı verilmesi gerektiğini belirleyen unsurlardan sayılabilir.

\section{Türkçenin telaffuzunda etkili olan ögeler}

Telaffuzda dilin bürünsel özelliklerinin doğru kullanılması hedef dilin seslerini, seslerin çıkış biçimleri ve yerlerini ayrıca hedef dilin seslerinin dilsel iletişim dizgesi sayılan fonolojinin özelliklerinin ana dilden ayırıcı özelliklerini bilmekten geçtiği düşünülmektedir. Bu bağlamda Aksan, yabancı dile ait

\footnotetext{
Adres | Address

RumeliDE Dil ve Edebiyat Araştırmaları Dergisi $\quad$ RumeliDE Journal of Language and Literature Studies Osmanağa Mahallesi, Mürver Çiçeği Sokak, No:14/8 $\quad$ Osmanağa Mahallesi, Mürver Çiçeği Sokak, No:14/8 Kadıköy - ISTANBUL / TURKIYE 34714 Kadıköy - ISTANBUL / TURKEY 34714 e-posta: editor@rumelide.com e-mail: editor@rumelide.com, tel: +90 505 7958124, +90 2167730616 phone: +90 505 7958124, +90 2167730616
} 
kelimeleri söylerken ortaya çıkan yetersizlik ve yanlışların ses aygıtlarından kaynaklanmadığını, kişinin ana dili ve öğrendiği ses dizgeleri arasında farklılar olsa da ses aygıtları arasında farklılık olmadığını belirtmektedir. Telaffuzda ortaya çlkan olumsuz durumların nedeni, ana dil ve yabancı dilin ses dizgesinin farklı olmasıdır. Ana dilinin ses dizgesine alışıı olan konuşur, yabancı seslerin ana dilin zihne yerleşmiş olan ses dizgesinden farklı olmasından ve konuşmayı sağlayan düzenin ve organların belli sesleri çıarmaya alışkın olmasından kaynaklı sorun yaşar (Aksan, 1975: 428). Başkan da Aksan’ın görüşünü destekler nitelikte, insanların konuşma organlarının sadece kendi dillerinin düzenine alışkın olduğundan, yabancı dili de bu düzene göre seslemek eğiliminde olduğunu, böylece ortaya, "yerli" ve "yabancı" biçiminde olmak üzere, iki türlü sesleme veya konuşma çıktığını ifade etmektedir (Başkan, 2006: 95). Daha farklı şekilde söylemek gerekirse, kendi ana dilinin kurallarına ve bu kurallara göre şekillenen konuşma organlarının düzenine göre telaffuzu kullanmaya alışkın olan konuşurlar, bir yabancı dille öğrenme ortamında karşılaştıklarında öğrenilen dilin telaffuzunu kendi ana dillerindeki gibi sesletme eğiliminde olmaktadır. Şenel de konuşma şeklimizin kimliğimizin bir parçası olduğunu yani diller arasındaki fonemik farklılıkların yabancı bir aksanla konuşulacak bir hedef dile neden olduğunu ifade etmektedir (Şenel, 2006: 113).

$\mathrm{Bu}$ bilgiler çerçevesinde Türkçenin karakteristik ses bilgisi özellikleri, dolayısıyla Türkçenin telaffuzunda etkili olan ögeler düşünüldügünde Türkçenin ünlüleri, ünsüzleri, ünlü, ünsüz uyumu, ünlü düşmesi, Türkçede uzun ünlü olmayışı, Türkçenin bürünsel özellikleri Türkçenin telaffuzunda etkili olan ögeler olarak sayılabilir.

Ünlüler açısından zengin kabul edilen Türkçeye karşılık (Aksan, 1999; Ergenç, 2002; Onan, 2014) ünsüzlere ortalama bir değer atfedilmektedir. Tecim, yaptı̆̆ı çalışmasında, Wals Info'ya göre bir dilin ünsüz dökümü bakımından ortalama olarak onaylanması en düşük 22 ünsüz olmak şartıyla, bu toplamdan üç ünsüz eksik ya da fazla değer taşımasına bağlı olarak Türkçenin ünsüzler bakımından ortalama, ünlüler bakımından ise geniş sınıfa sokulduğunu ifade etmektedir (Tecim, 2017: 44-50). Türkçe açısından düşünüldüğünde ünlüler açısından diğer dillere göre zengin kabul edilen Türkçenin sesletiminde, yabancı dil öğrenicileri tarafından özellikle konuşma becerisinde, sayıca ortalama bir değere sahip ünsüzlere nazaran sorun yaşanabilmektedir (Ermağan, 2021b: 32).

Türkçenin telaffuzunda etkili olabilecek ögelerden biri de, Türkçenin karakteristik özelliklerinden sayılan ses uyumuna sahip olmasıdır. Ünlüsü bol bir dil olan Türkçenin en tipik özelliği, benzeşme adı verilen ünlü ve ünsüz uyumlarıdır (Ergenç, 2002: 18). Türkçenin bir başka özelliği de yapısı gereği ilk hecede ünsüz yığılmasına yer vermemesidir. Ergenç, ünsüz yı̆̆ılmasını aynı seslem içinde ön veya son seste birden daha fazla ünsüzün bulunması şeklinde tanımlayarak bulunduğu dilin seslem düzeniyle sıkı sıkıya bağlantılı olup, seslem yapısının kuralları gereği ön seste yığılmaya izin vermediğini açıklamaktadır (Ergenç, 1989: 252-254). Türkçedeki ünlü, ünsüzler ve ses uyumlarının dışında Türkçede uzun ünlü bulunmaması da telaffuzda göz önünde bulundurulması gereken maddelerdendir. Dilimizde ünlülerin uzunluk-kısalık karşıtlığının başka dillerdeki kadar belirleyici olmasa da var olanların ayırıcı özellik taşıdıklarından sesbirim ya da anlam ayıııcı birim olarak kabul edilmeleri gerekmektedir (Ergenç, 1989: 35).

Türkçenin hece yapısı ve eklemeli bir dil olması da telaffuza etki eden ögelerden sayılabilir. Onan, Türkçe kelimelerdeki hecelerin düzenli ve tek doruklu olduğunu, Türkçenin eklemeli bir dil olmasının mevcut hece sistemini etkilemediğini ve hece yapısındaki bu sistemin Türkçe kelimelere bir söyleyiş kolaylı̆̆ sağladığını ortaya koyar. Ayrıca, ses benzerliği olan kelimelerin, sözlü iletişimde soruna neden olup iletişimi zorlaştırabildiğini, bir dildeki kelimede hece çeşidinin fazla olmasına bağlı olarak firkatif kelime

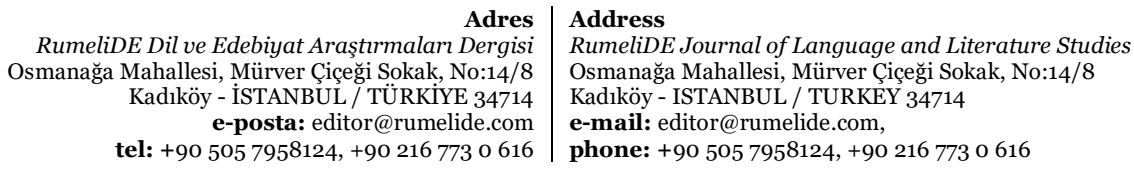


sayısının azalacağını ve buna bağlı olarak dilin anlaşılma oranın da yükseleceğini ifade edip kelime başına düşen hece değeri bakımından Türkçenin anlaşılma oranı yüksek bir dil olduğu çıkarımına ulaşmaktadır (Onan, 2014: 180).

Türkçenin ses bilgisel ve yapı bilimsel özelliği dışında telaffuza etki eden başka ögeler de bulunmaktadır. Aksan, ses düzeninin bir dilin sesleri ve niteliklerini içerdiğini, bunların seslerin çıkış yerleri, çıkış şekilleri, o dile ait ses eğilimleriyle, kısalık, uzunlukları ve dilin bürünsel özelliğini gösteren ezgi, vurgu, ton olduğunu ifade etmektedir (Aksan, 1999: 19).

Aycan'a (2012) ve Lam, Tjaden ve Wilding (2012) adlı araştırmacılara göre, konuşma sırasında seslerin gerekli sürede çıarılması, dil, dudak, çene gibi konuşma organlarının gerektiği gibi hareketi, sesin şiddetinin içerikle orantılı olarak bir miktar artırılması ya da azaltılması anlaşılırlığı artırmaktadır. Ayrıca tane tane konuşma ve sesi belli bir oranda yoğunlaştırma ile anlaşılırlık arasında doğrudan bir ilişki bulunmaktadır (akt: Şenyiğit ve Okur, 2019: 521).

Türkçenin telaffuzunda etkili olan bu ögelerin telaffuzun öğretilmesinde nasıl uygulanabileceği konusu dil öğretiminde güçlük oluşturmaktadır. Bu noktada Başkan, yabancı dilin ses düzenini öğretmeye gelince, bu yolda yapılacak tek şeyin, Türkçenin ses düzeni ile yabancı dilinkini karşılaştıran bir yöntemi uygulamak olduğunu belirtmektedir. Her iki düzende, ortak sesler ve özellikler ile birbirlerine iyice aykırı olanlar belirtildikten sonra öğrenicinin hangi yabancı sesleri, kendi dilindeki sesler gibi söyleyeceği bildirilerek, aykırı olanların da, Türkçedeki seslerden ne gibi noktalarda ayrıldıkları gösterildikten sonra, konuşma organlarının, nasıl kullanılarak bu sesleri çıarabilecekleri, çeşitli resimlerle, çizimlerle ve sesleme örnekleriyle gösterilebileceğini açıklamaktadır (Başkan, 2006: 96). Hedefe yönelik telaffuz öğretiminde iki dilin ses bilgisel düzendeki farklılı̆̆ına vurgu yapmanın önemine bir başka araştırmada daha yer verilmiştir. Schatz’a (2006) göre, amaca yönelik telaffuz alıştırmaları için her şeyden önce ana dil ile öğrenilen yabancı dil arasında cümle melodisi, cümle vurgusu, sesler, ses kombinasyonları alanlarında fonetik farklılıkların neler olduğunun açı̆̆a kavuşturulması gerekmektedir (akt: Demir, 2013: 123-124).

\section{Problem}

Alanyazında konuşma becerisi ve alt ögesi olan telaffuzla ilgili yapılan çalışmalar araştırıldığında bu çalışmaların daha çok öğrenicilerin yaşadığı telaffuz sorunlardan hareketle ele alındığı saptanmıştır. Yabancı dil olarak Türkçenin öğretiminde kullanılan ders kitaplarında telaffuz konusunun araştırılmasında ise en çok telaffuz etkinliğinin bulunduğu A1 seviyesi kitaplarının veri kaynağı olarak kullanıldığı tespit edilmiştir.

Bu nedenle buradan hareketle şu soruları sormak gerekir:

1.Telaffuz öğretimi, temel seviye için yazılan kendi kendine dil öğrenme kitaplarında öğrenicinin yaşayabileceği telaffuz sorunlarından hareketle mi ele alınmıştır?

2.Bu kitaplarda, ders kitaplarından farklı olarak telaffuz öğretiminin uygulanışı karakteristik özellikler taşımakta mıdır?

3.Telaffuzla ilgili etkinlikler, alıştırmalar, temel seviye için yazılan kendi kendine dil öğrenme kitaplarında temel seviye düzeyinde verilmekte midir?

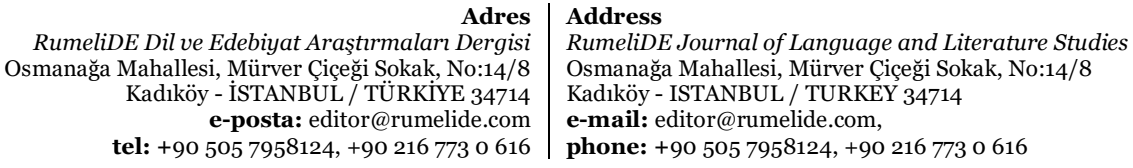




\section{Önem}

İncelenen kitapların çoğunluğu internetin ortaya çıkışından, 1989 yılından önce oluşturulmuştur. Dolayısıyla dil eğitiminde internetin kullanılmaya başlamasından önce yazılan bu kitaplar, dil eğitiminde ana kaynak olma özelliğini taşımaktadır. Dil öğrenmek isteyenlerin kısıtlı da olsa ulaşabildikleri tek kaynak olma özelliği taşıması bakımından önemlidir.

Ayrıca kendi kendine dil öğrenme kitaplarında konuşma becerisi öğrenenin karşısındaki muhatap yokluğu göz önüne alındığında ve konuşma becerisinin ediniminde telaffuz ögesi önemli bir nokta oluşturduğu için titizlikle üzerinde durulması gereken hususlardandır.

Telaffuz öğretiminin kendi kendine Türkçe öğrenme kitaplarında nasıl ele alındığını, telaffuz öğretiminin bu tür kitaplarda ele alınışnı irdeleyen bir çalışma tespit edilmemiştir. Bu çalışma; telaffuz öğretiminin bu tür kitaplarda nasıl incelendiğini araştırması ve buradan yola çıkarak hangi etkinlik ve araştırmaların uygulanabileceği açısından önemlidir.

\section{Amaç}

Örnekleme alınan 20. yüzyllda farklı hedef kitlelerine yönelik Türk ve yabancı yazarlar tarafından Türkçe-İngilizce olarak yazılmış 10 kitapta telaffuza yönelik yöntem ve uygulamaları tespit etmektir. Bu kitaplardaki telaffuz öğretiminin nasıl ele alındığını inceleyip, buna alternatif olarak nelerin yapılabileceğini ortaya koymaktır.

$\mathrm{Bu}$ amaç doğrultusunda, Türkçenin telaffuzunu etkileyen ögeler, incelenen kitaplarda yer alma biçimi açısından irdelenerek telaffuz öğretimini etkileyen hangi alt ögelere nasıl yer verildiği, kitapların hedef kitlesinin, yazılış amacının ve yönteminin telaffuz öğretiminde etkili olup olmadığını incelemek amaçlanmıştır.

\section{Yöntem}

\section{Araştırmanın modeli}

Çalışmada, yöntem olarak betimsel tarama kullanılarak, literatür taraması ve doküman incelemesi yaklaşımıla veriler analiz edilmiştir.

Literatür taramasını Gash belirli bir konuda yayınlanmış olabildiğince çok eserin derinlemesine ve sistematik olarak araştırılması ve belirlenmesi olarak tanımlamıştır (Akt. Köroğlu, 2015: 61). Doküman incelemesi, araştırılması hedeflenen olgu veya olgular hakkında bilgi içeren yazılı materyallerin analizini kapsamaktadır (Yıldırım ve Şimşek, 2008: 188).

\section{Verilerin toplanması ve analizi}

Betimsel analiz için kavramsal çerçeve "Türkçenin telaffuzunda etkili olan ögeler, telaffuz öğretiminde etkili olan ögeler" olarak belirlenmiştir. Bu nedenle Türk ya da yabancı yazarlar tarafından Türkçeİngilizce iki dilli olarak başlangıç seviyesindeki öğreniciler için farklı hedef kitle ve amaçlarına yönelik olarak 20. yüzyılda İngilizce-Türkçe olarak iki dilli yazılmış kendi kendine dil öğrenme kitapları seçilmiştir.

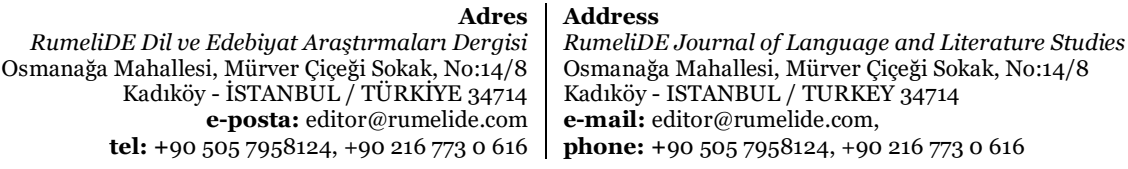


İncelenen kitaplar aşağıda sıralanmıştır.

- Attaoullah, F. (1942). Turkish Self-taught by Natural Method with English Phonetic Pronunciation. Londra: E. Marlborough \& Co.ltd.

- War Department (1943). Turkish: A guide to the spoken language. Washington.

- $\quad$ Editions Berlitz S.A. (1975). Turkish for travellers. Belgium.

- Mandil, D. (1977). Turkish Made Easy. İstanbul: Öğretim Yayınevi.

- Mughul, Y.M. (1979). Modern Turkish For Beginners. İstanbul: İstanbul Matbaası.

- Hengirmen, M. (1988). Turkish for Travellers. Ankara: Engin Yayınevi

- $\quad$ Rona, B. (1989). Get By In Turkish. England: Belmont Press

- Teymur N. (1989) Quick \&Easy Turkish. Great Britain: Headway.

- Rona, B. (1989). Turkish in Three Months. Great Britain: Hugo's Language Books.

- Çağa, T. ve G. (1990). Turkish in a Week. Great Britain: Headway.

Çalışmanın ikinci aşamasında örneklem olarak alınan kitaplar, telaffuz öğretimiyle ilgili bir yönerge ya da uygulama içerip içermediği, kullanılan yöntem ve teknik çerçevesinde yazılı açılklama ve görsel ögelerden faydalanıp faydalanmadığı noktasında nitel veri toplama araçlarından biri olan doküman incelemesi yöntemiyle incelenmiştir. Doküman analizi, araştırılması hedeflenen olay ve olgulara dair bilgi içeren yazılı materyallerin analizini kapsar (Tanrı̈ğgen, 2009: 239). Bu çalışmada ilgili dokümanlar tetkik edilmiş, elde edilen çeşitli veriler incelenerek amaçlar doğrultusunda birtakım sonuçlara ulaşılmıştır.

\section{Bulgular}

Seçilmiş kitapların içeriği, telaffuzla ilintili olduğu düşünülen hedef kitle, yazılış amacı, dil öğretim yöntem ve teknikleri ve telaffuz öğretiminin genel olarak nasıl yapılması gerektiği ve Türkçenin telaffuzuna etki eden ögeler göz önünde bulundurularak incelenmiştir.

Turkish Self-taught by Natural Method with English Phonetic Pronunciation adlı eser, dil öğretim metotlarından doğal yöntem kullanılarak İngilizce konuşan öğrenicilere Türkçe öğretmek amacıyla 1942 yllında yazılmıştır. Eserde telaffuz rehberine kaynaklık eden fonetik bölümün ayrıntılı olarak hazırlandığı tespit edilmiştir. Bölümde, alfabe, çeşitli ünlülerin farkı üç özel karakter (â, î, û), vurgu, yabancı sözcüklerde vurgu, hecelerin oluşumu, ünlüler, ünsüzler, Türkçe sözcüklerin yapısı ve fiil kökleri, kök sözcükler ve son ekler, seslerin sınıflandırılması, seslerin tekrarı, seslerdeki değişim, dilin uyum ve akıcıllı̆̆ı, ses benzeşmesi, sert ve yumuşak seslerin yabancı kelimeler üzerindeki etkisi, k ve $\breve{g}$ seslerinin durumu ayrıntılı olarak Şekil 1'de görüldüğü gibi yer almaktadır.

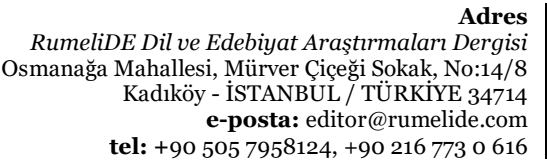

RumeliDE Dil ve Edebiyat Araştırmaları Dergisi Kadıöy - İSTANBUL / TURR tel: +90 $5057958124,+902167730616$
Address

RumeliDE Journal of Language and Literature Studies

Osmanağa Mahallesi, Mürver Çiçeği Sokak, No:14/8

Kadıköy - ISTANBUL / TURKEY 34714

e-mail: editor@rumelide.com,

phone: +90 505 7958124, +90 2167730616 


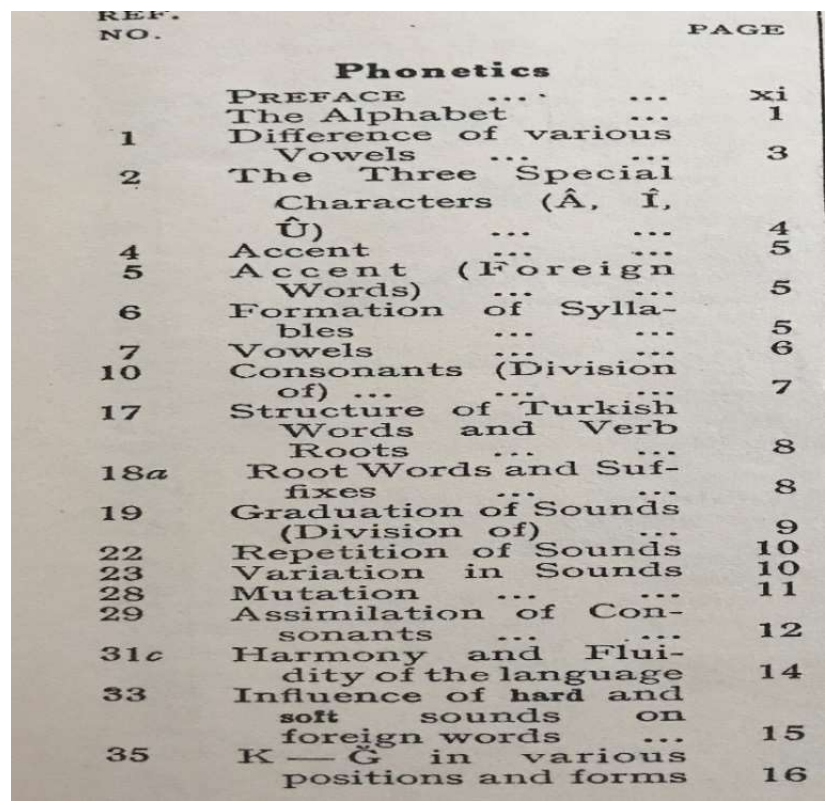

Şekil 1: Kitabın fonetik bölümünün içeriğini gösteren görsel (Attaoullah, 1942: vii)

Çalışmada incelenen diğer kitaplara nazaran, ünlü ve ünsüzler hakkında detaylı bilgi verildiği, harflerin büyük ve küçük harf olarak yazımı, seslerin sadece İngilizceden hareketle değil Almanca ve Fransızcadan hareketle nasıl telaffuz edileceği ve fonetik kullanımı da Şekil 2'deki gibidir.

\begin{tabular}{|c|c|c|c|}
\hline & acter & Name & Pronunciation \\
\hline A & $\mathrm{a}$ & A & $\begin{array}{l}\text { as the sound of } u \text { in the English } \\
\text { words sun, } u p\end{array}$ \\
\hline$\hat{A}$ & $\hat{a}$ & $\mathrm{AA}$ & $\begin{array}{l}\text { (1) as the sound of } a \text { in the English } \\
\text { words car, father } \\
\text { (2) except when following a } \dot{k} \text { or } g \text {, } \\
\text { when the sound of an } i \text { is } \\
\text { inserted before the } a \text {, making } \\
\text { it sound as if written kia or gia (see } \\
\text { also Ph. 3) }\end{array}$ \\
\hline B & $\mathrm{b}$ & $\mathrm{BE}(\mathrm{h})$ & $\begin{array}{l}\text { as the sound of } b \text { in the English } \\
\text { word bat }\end{array}$ \\
\hline C & C & $\mathrm{JE}(\mathrm{h})$ & $\begin{array}{l}\text { as the sound of } j \text { in the English } \\
\text { word jump }\end{array}$ \\
\hline$C$ & $c$ & $\mathrm{CHE}(\mathrm{h})$ & $\begin{array}{l}\text { as the sound of ch in the English } \\
\text { word church }\end{array}$ \\
\hline D & d & $\mathrm{DE}$ & $\begin{array}{l}\text { as the sound of } d \text { in the English } \\
\text { word } d 0 \mathrm{~g}\end{array}$ \\
\hline
\end{tabular}

Şekil 2: Seslerin yazılışı, okunuşu, telaffuzu ve fonetik kullanımını gösteren görsel (Attaoullah, 1942: 1)

Kitapta kullanılan yöntem, doğal yöntem olduğu için sözlü dilin günlük kullanımındaki sözcükleri seçilerek İngilizce karşılıklarıyla birlikte telaffuzları sıralanmıştır. Ayrıca konuşma cümleleri ve kalıp ifadeler de Şekil 3’te görüldüğü gibi telaffuzlarıyla birlikte verilmiştir.

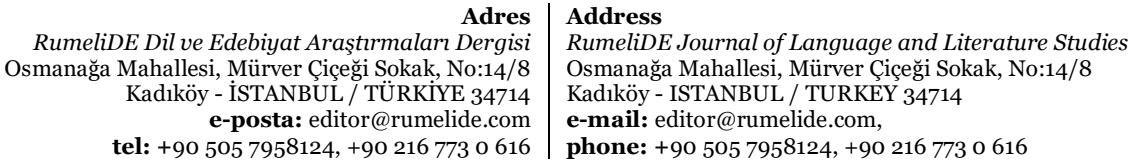




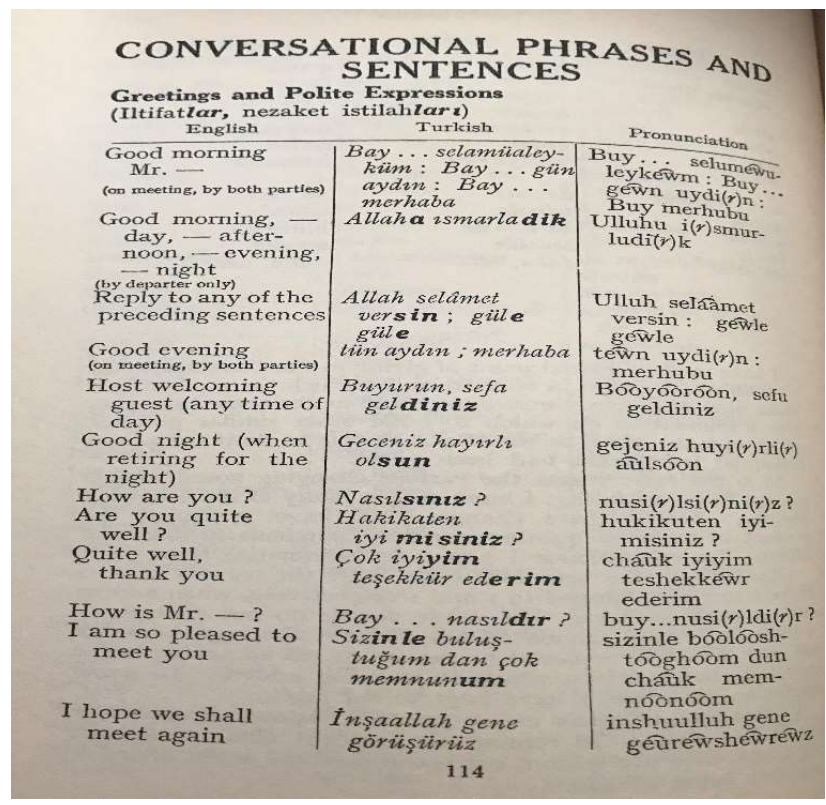

Şekil 3: Konuşma cümleleri ve kalıp ifadeleri gösteren görsel (Attaoullah, 1942: 114)

Kitabın içeriğinde kelime ve cümleler telaffuzlarıyla birlikte verildiğinden kitabın sonunda tekrar bir sözlük yer almamaktadır. Bu eserde, telaffuz öğretiminde görsel ögelerden yararlanılmadığı gibi telaffuz alı̧şırmalarına da yer verilmemiştir.

Turkish: A guide to the spoken language adlı eser, Amerikan askerlerine başlangıç seviyesinde Türkçe öğretmek, dilde basit konuşmalar yapılmasını sağlamak amacıyla 1943 yılında yazılmıştır (Ermağan, 2021a: 43-47). Bu eserde işitsel-dilsel yöntem kullanılmıştır. Bu kitapta telaffuz hakkındaki bilgiler "Telaffuz Hakkında İpuçları" şeklinde giriş kısmında paylaşılmıştır. Bu kısımda, tüm kelime ve ifadelerin İngilizce gibi okunan bir yazımla yazıldığı ve her harf veya harf kombinasyonunun, genellikle İngilizcede temsil ettiği ses için kullanıldığı ifade edilmektedir. Bu nedenle, oo'nun her zaman too, boot, tooth, roost kelimelerinde olduğu gibi telaffuz edilerek başka bir şekilde telaffuz edilmediği belirtilmektedir. Kitapta, öğreniciye bu kelimeleri söyledikten sonra ünlülerini kendi kendine telaffuz etmeleri tavsiye edilmektedir. Telaffuz sütununda oo'yu her gördüklerinde kullanmaları gereken sesin bu olduğunu, blood ve door kelimelerinde yer alan oo sesini kullandıklarında yanlış anlaşılabileceklerini belirtmektedir. Kitapta ayrıca hece vurgusuna da değinilmiş olup, diğerlerinden daha sesli okunan hecelerin kitapta büyük harfle yazıldı̆̆ı, kavisli çizgilerin ise ara vermeden birlikte telaffuz edilen sesleri göstermek için kullanıldığı ifade edilmektedir. Aşağıdaki görsel bu durumu örneklendirmektedir.

Adres
RumeliDE Dil ve Edebiyat Araştırmaları Dergisi Osmanağa Mahallesi, Mürver Çiçeği Sokak, No:14/8 Kadıköy - ISTANBUL / TÜRKIYE 34714 e-posta: editor@rumelide.com tel: +90 505 7958124, +902167730616
Address

RumeliDE Journal of Language and Literature Studies Osmanağa Mahallesi, Mürver Çiçeği Sokak, No:14/8

Kadıköy - ISTANBUL / TURKEY 34714

e-mail: editor@rumelide.com

phone: +90 505 7958124, +90 2167730616 


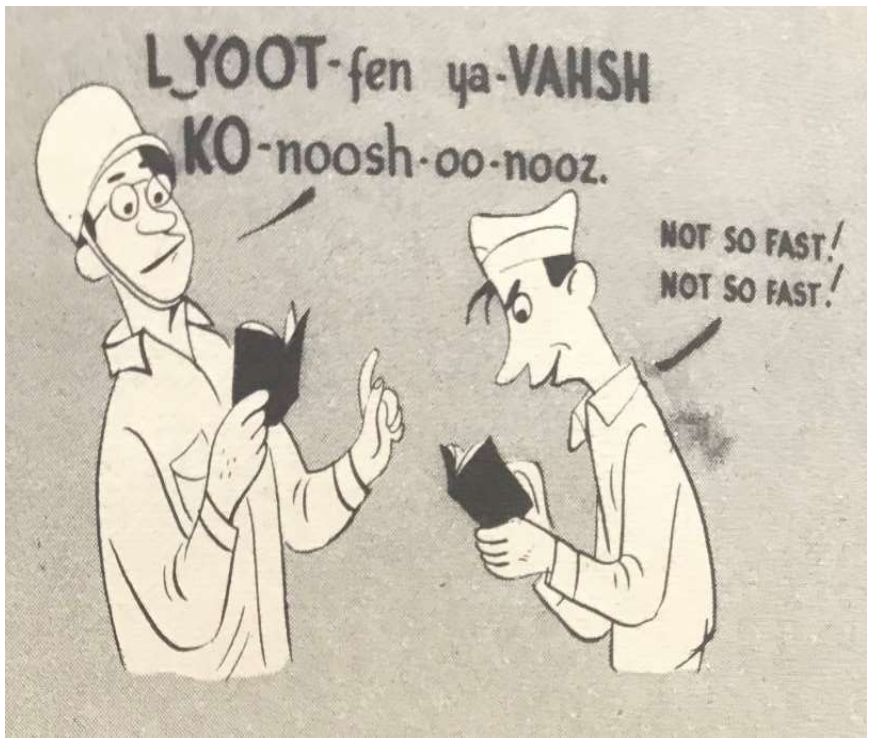

Şekil 4: Vurgulu söylenmesi gereken heceleri gösteren görsel (War Department, 1943: 14)

Bir başka görselde ise g sesinin telaffuzuna dikkat çekilmektedir.

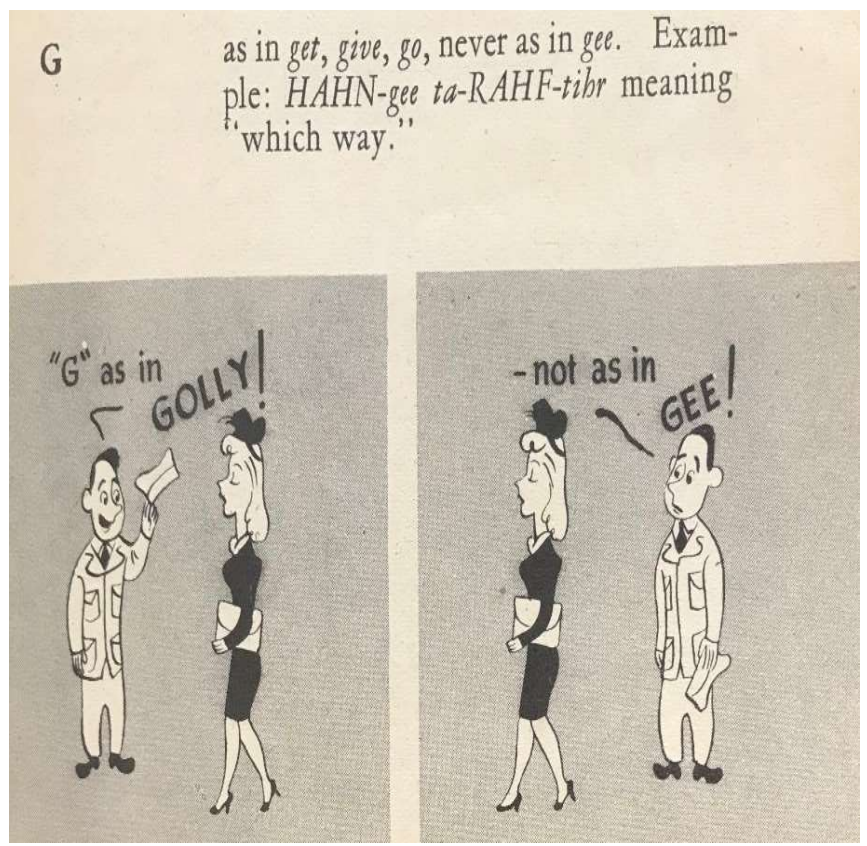

Şekil 5: G sesinin telaffuzuna dikkat çeken bir görsel (War Department, 1943: 11)

İncelenen bu eserde, Türkçenin seslerine, hece vurgusuna hem yazılı açıklamalarla hem de görsellerle dikkat çekilmeye çalışılmıştır.

Kitapta telaffuz alıştırmalarına kitabın yöntemi olan işitsel-dilsel yönteme uygun olarak yer verilmektedir. Kelime alıştırmalarında seçenekler İngilizce telaffuz göz önünde bulundurularak verilmiş ve öğreniciye cevapları da verilerek kendi kendilerini test etmeleri istenmektedir. Ayrıca kitapta yine

\footnotetext{
RumeliDE Dil ve Edebiyat Araştırmaları Dergisi Osmanağa Mahallesi, Mürver Çiçeği Sokak, No:14/8 Kadıköy - ISTANBUL / TÜRKIYE 34714 e-posta: editor@rumelide.com Address

RumeliDE Journal of Language and Literature Studies Osmanağa Mahallesi, Mürver Çiçeği Sokak, No:14/8 Kadıköy - ISTANBUL / TURKEY 34714

e-mail: editor@rumelide.com tel: +90 505 7958124, +90 216773 o 616 phone: +90 505 7958124, +90 2167730616
} 
kitabın yöntemine uygun olarak öğreniciden her kelimeyi duyduktan hemen sonra yüksek sesle tekrar edip Türkçe konuşanın yaptığı gibi söylemelerini ve telaffuzu olabildiğince yakından taklit etmelerini hatta alışılmadık bir aksanı olan birini taklit etmeleri de tavsiye edilmektedir. Telaffuzun her detayını, ritmi ve tonlamayı bile almaya çalışmalarını öğütleyen kitap, öğreniciye kitaptaki kelimeleri takip etmelerini ancak bunların yalnızca bir hatırlatma olarak kullanılması gerektiğini ifade etmektedir. Kitap bunların dışında öğrenicilere yazılı olarak gördüklerinden farklı bir şey duymaları durumunda duyduklarına göre hareket etmeleri gerektiğini, bir dilin sesinin yalnızca yazılı sözcükten alınamayacağını, kulakların gözlerden daha fazla kullanılması gerektiğini belirtir. Kitap ses kayıtlarıyla birlikte düzenlendiği için, öğrenicide kayıtların olmaması ve kelimelerin bir Türkçe konuşana okutulmadığı durumda telaffuzla ilgili ipuçlarına güvenmeleri gerektiğini ortaya koymaktadır. Kitapta, sözlük yerine alfabetik kelime listesi kelimelerin sesletimiyle birlikte verilmiştir.

Turkish For Travellers adlı kitap, gezginlere yönelik olarak Türkiye'yi ziyaret etmeleri sirasında seyahatlerinde yardımcı olmak ve Türkiye'deki hayata dair giriş niteliğinde bilgi sunmak maksadıyla 1975 yllında kaleme alınmıştır. Kitapta, telaffuza giriş bölümü yer almaktadır. Kitap, bu bölümle transkripsiyona aşina olunmasını ve dolayısıyla Türkçenin seslerine alışılmasına yardımcı olmayı amaçlamaktadır.

İletişimsel yaklaşıma göre yazılan kitapta, günlük yaşama göre seçilen ünite başlıkları altında kelime ve cümlelerin telaffuzu İngilizce söylenişe göre yapılmıştır. Türkçenin seslerinin çok ayrıntıya girilmeden genel hatlarıyla açıklandığı kısımda öğreniciye Türkçe seslerin telaffuzlarını ve ayrıca transkripsiyonlarda kullanılan sembolleri bulacakları belirtilip öğrenicileri, Türkçede, İngilizcede olmayan bazı özel işaretli harflerin olduğu konusunda uyarmaktadır.

Taklit edilen telaffuzun, belirtilen özel kurallar dışında, İngilizceymiş gibi okunması gerektiğini herhangi iki dilin seslerinin hiçbir zaman tam olarak aynı olmadığını vurgulayarak tavsiye etmektedir. Eserde, verilen işaretlerin dikkatli bir şekilde takip edilmesi durumunda transkripsiyonları, öğrenicinin kendi kendine anlayacak şekilde okumakta zorluk çekmeyeceği belirtilmektedir.

Kitapta ünlüler, ünsüzler, uzun ünlüler, ikiz ünlüler, çift ünsüzler, gırtlak ünsüzü ve vurgu başlıkları ayrıca ekler ve ünlü uyumu hakkında bilgi veren bölümler bulunmaktadır. Bu başlıklardan önce, kalın harflerle gösterilen harflerin diğerlerinden daha fazla vurgu (yüksek sesle) ile okunması gerektiği vurgusu yapilmaktadır.

Belirlenen konu başlıklarıyla ilintili olarak verilen kelime ve cümlelerin telaffuzu, kitabın içerisinde İngilizce telaffuzlarıyla birlikte verilmiştir. Görsel ögelerden telaffuz öğretiminde yararlanılmadığı gibi kitabın arkasında bir sözlük bulunmamaktadır. Ayrıca kitapta telaffuz alıştırmaları da bulunmamaktadır.

Bu kitapta diğer kitaplardan farklı olan özellik, seslerin genel İngilizcede nasıl telaffuz edildiğiyle ilgili verilen karşılaştırmalı telaffuzun dışında, bir sesin kuzey İngilizce aksanıyla karşılaştırmalı verildiğini gösteren bir açılamaya da yer vermesidir.

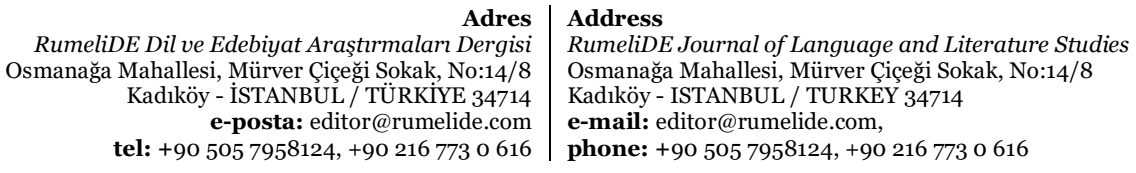




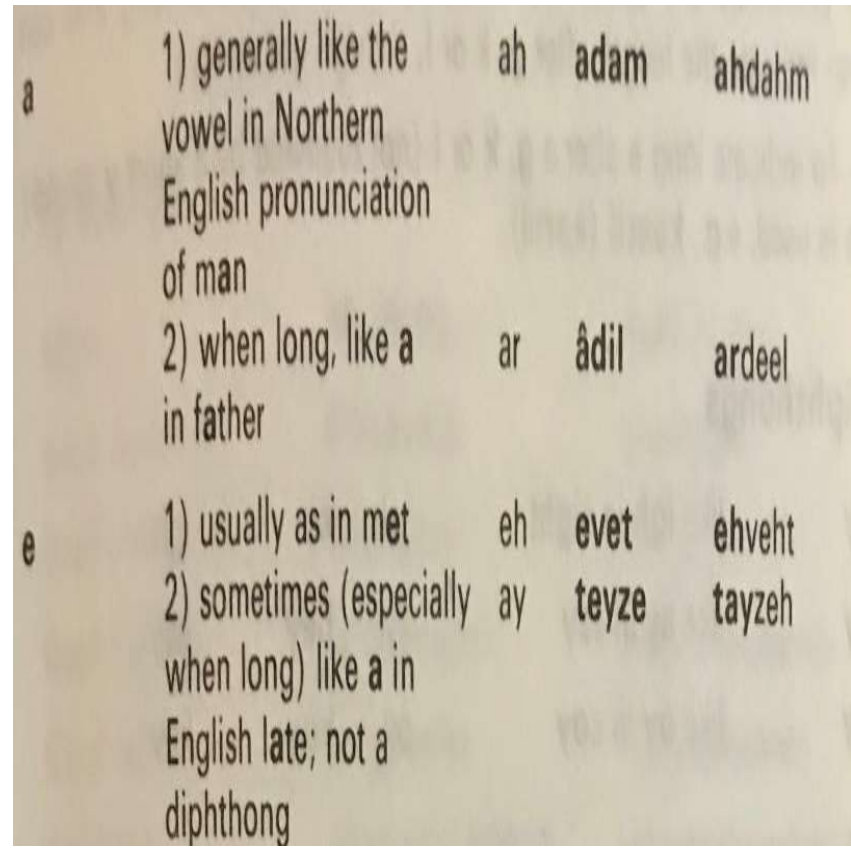

Şekil 6: A ünlüsünün Kuzey İngilizcesinde telaffuzunu örnekleyen görsel (Editions Berlitz S.A. 1975: 9)

Turkish Made Easy adlı yapıt, 1977 ylında yazılmış olup İngilizce konuşanlara ve İngilizce konuşan turistlere yönelik olarak Türkçeye atılan ilk adımları basit ve ilgi çekici bir şekilde sunmayı amaçlar. Aynı zamanda İngilizce konuşan turistler için çekicidir. Turistlerin, duyduklarını, okuduklarını anlamalarını ve günlük işlerinde kendilerini ifade etmelerini sağlayarak kaldıkları sürenin tadını daha çok çıarmalarını amaçlamaktadır. Turkish Made Easy adlı eserde dilbilgisi-çeviri yöntemi ağırlıklı bir yöntem olarak seçilip Türkçe kelime ve cümlelerin İngilizce karşllıkları verilmiştir. Buna karşın, dilbilgisi-çeviri yönteminin önem vermediği konuşma becerisi dolayısıyla telaffuz öğretimini destekleyecek şekilde kelime ve cümlelerin İngilizceden hareketle sesletimine de yer verilmiştir. Telaffuz etkinliklerine yer vermeyip, dilbilgisine yönelik etkinlikler cevap anahtarıyla birlikte verilmiştir. Giriş bölümünde Türkçe alfabe hakkında bilgi verilirken seslerin çıkarılışı hakkında İngilizcedeki kelimelerde yer alan seslerin söylenişinden yola çıarak açıklama yapılmıştır. Kitap sonunda, Türkçe kelimeler madde başı yapılarak kelimelerin telaffuzuna da yer verilmiştir ancak telaffuz öğretiminde görsel ögelerden yararlanılmamıştır.

RumeliDE Dil ve Edebiyat Araştırmaları Dergisi Osmanağa Mahallesi, Mürver Çiçeği Sokak, No:14/8 Kadıköy - ÍSTANBUL / TÜRKIYE 34714 e-posta: editor@rumelide.com tel: +90 505 7958124, +90 2167730616
Address

RumeliDE Journal of Language and Literature Studies Osmanağa Mahallesi, Mürver Çiçeği Sokak, No:14/8

Kadıköy - ISTANBUL / TURKEY 34714

e-mail: editor@rumelide.com,

phone: +90 505 7958124, +90 2167730616 


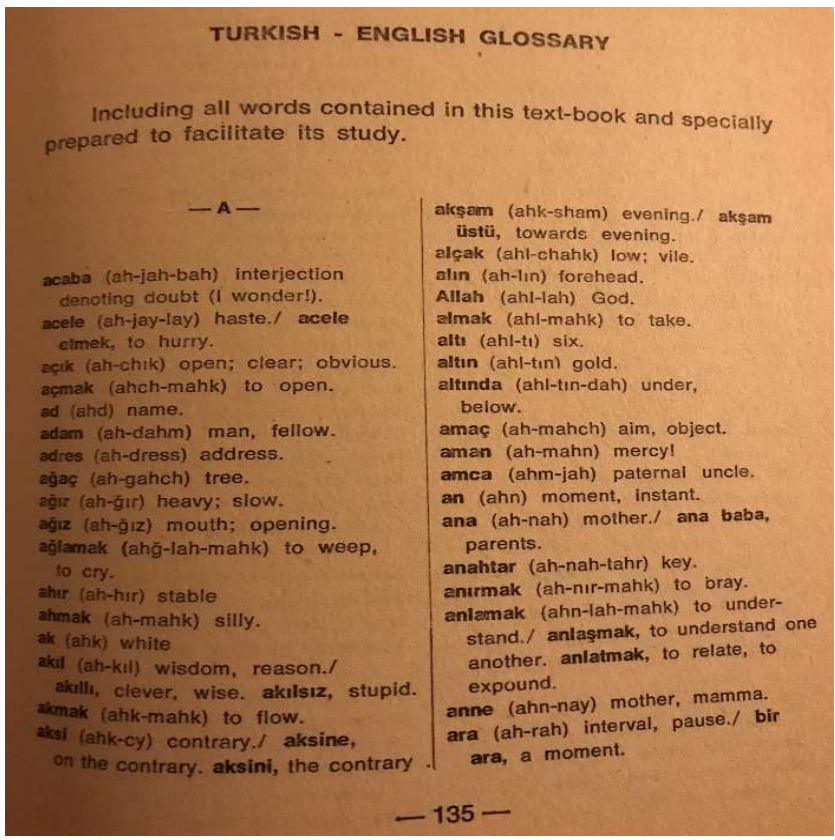

Şekil 7: Kitapta yer alan Türkçe-İngilizce sözlük (Mandil, 1977: 135)

Modern Turkish For Beginners adlı eser, 1979 yllında İngilizce konuşanlara yönelik (Pakistanlı ve diğer yabancı öğreniciler) yazılmış olup öğretmen yardımı olmadan dikkatli ve bir şekilde incelenerek öğrenicinin altı ay içinde Türk diline ilişkin geçerli bir bilgi edinmesini amaçlamaktadır. Bu eserde dilbilgisi-çeviri yöntemi kullanılmıştır.

Eserde ünlü, ünsüzler ve bu ünlü ve ünsüzlerin İngilizce kelimelerden yola çıkılarak nasıl sesletileceği hakkında yazılı açıklama yapılırken nasıl sesletileceği gösterilmemiştir. Ünlü ve ünsüz uyumu hakkında bilgi verilerek örneklendirilmiştir.

Kitapta görsel ögelerden ve sözlükten yararlanılmadığı gibi, diğer kitaplardan farklı olarak kelime ve cümlelerin nasıl sesletileceği gösterilmemiştir. Bunda da kitapta dilbilgisi-çeviri yönteminin etkili olduğu düşünülebilir.

Kitabın giriş kısmında, Latin harfli Yeni Türk Alfabesinin 3 Kasım 1928'de kabul edildiğine değinilip,

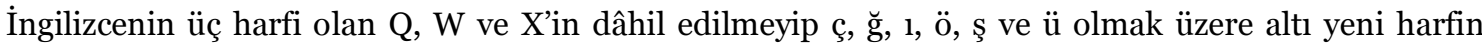
eklendiği ifade edilmektedir. Modern Türk alfabesinin sekizi ünlü ve yirmi birinin ünsüz olup 29 harften oluştuğunu, Türkçe yazımın fonetik olduğunu yani her harfin tek bir sese karşıllı geldiğini belirtmektedir. Türkçede tek sesi oluşturan iki harf ve diftong olmadığını, iki sesli harf bir araya geldiğinde, her birinin kendi sesini koruduğunu ifade etmektedir. Türkçede her kelimenin yazıldığı gibi okunduğunu, tek istisnanın, ğ olarak yazllan ve takip ettiği ünlünün sesini uzatmaya yarayan "yumuşak" "g" olduğunu açıklamaktadır. Kitapta telaffuz öğretiminde görsel ögelerden de yararlanılmamıştır. Ayrıca telaffuz alıştırmaları bulunmayıp, İngilizceden Türkçeye, Türkçeden İngilizceye çeviri alıştırmaları, boşluk doldurma alıştırmaları olmak üzere dilbilgisi-çeviri yöntemine uygun alıştırmalar seçilmişsir.

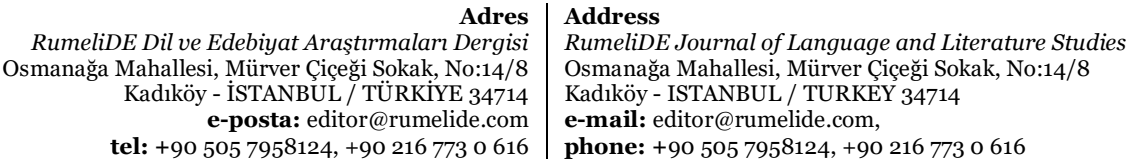

RumeliDE Dil ve Edebiyat Araştırmaları Dergis tel: +90 $5057958124,+902167730616$

phone: +90 505 7958124, +90 2167730616 


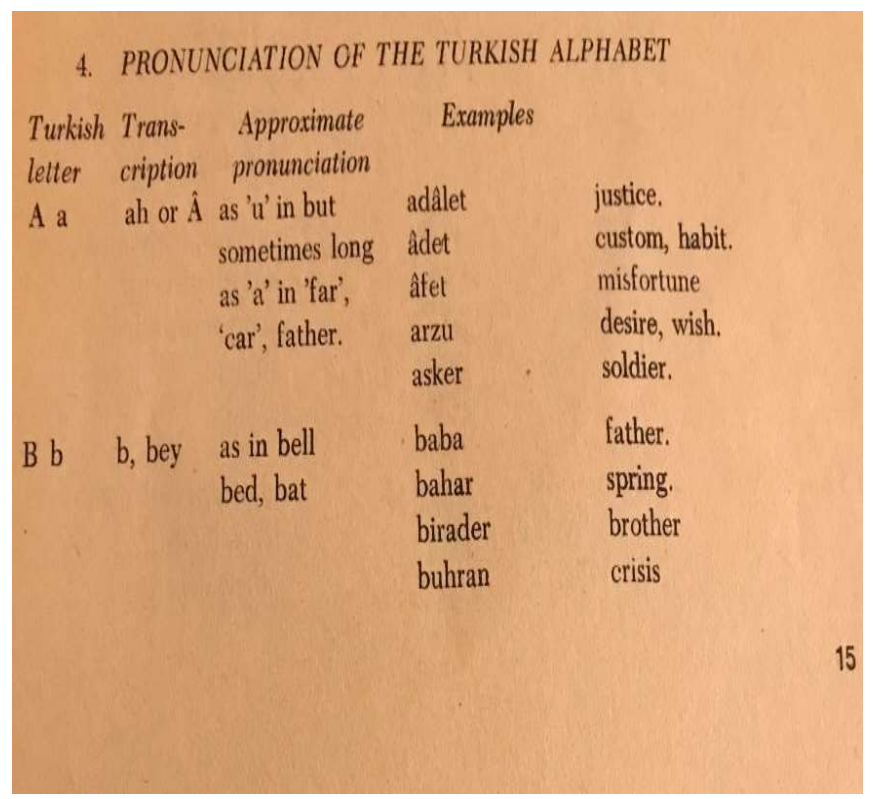

Şekil 8: Türkçe kelimelerin seslendirilişini göstermeyen görsel (Mughul, 1979: 15)

Turkish for Travellers adlı eser 1988 ylında yayımlanmıştır. Tatilini Türkiye'de geçirmek isteyen fakat Türkçe bilmeyenlere yönelik Türkiye'de kaldıkları süre boyunca iletişim sorunlarını çözmeyi amaçlamaktadır. Bu eser, iletişimsel yaklaşıma göre yazılmıştır.

Kitapta telaffuz rehberi bulunmakla birlikte, burada öğrenicinin Türkçe kelimelerin telaffuzlarının transkripsiyonlarını bulabileceğini ve transkripsiyonların İngilizceymiş gibi okunması gerektiğini belirtmekte birlikte Türkçe ve İngilizce seslerin tam olarak aynı olmadığını ancak kelimelerin yaklaşık telaffuzunun anlaşılır olacağını ifade etmektedir. Kitapta ünsüzler, ünlüler ve diftonglar hakkında bilgi verilmektedir. Kitap içerisinde telaffuz öğretimini destekleyen görseller ve kitap sonunda sözlük bulunmamaktadır. Buna karşılık kelime, kalıp ifade ve cümlelerin telaffuzunu kitabın tamamında gösteren örnekler bulunmaktadır. Ayrıca bu kitapta alıştırma bulunmamaktadır.

RumeliDE Dil ve Edebiyat Araştırmaları Dergisi Osmanağa Mahallesi, Mürver Çiçeği Sokak, No:14/8 Kadıköy - ÍSTANBUL / TÜRKIYE 34714 e-posta: editor@rumelide.com tel: +90 $5057958124,+902167730616$
Address

RumeliDE Journal of Language and Literature Studies Osmanağa Mahallesi, Mürver Çiçeği Sokak, No:14/8

Kadıköy - ISTANBUL / TURKEY 34714

e-mail: editor@rumelide.com,

phone: +90 505 7958124, +90 2167730616 


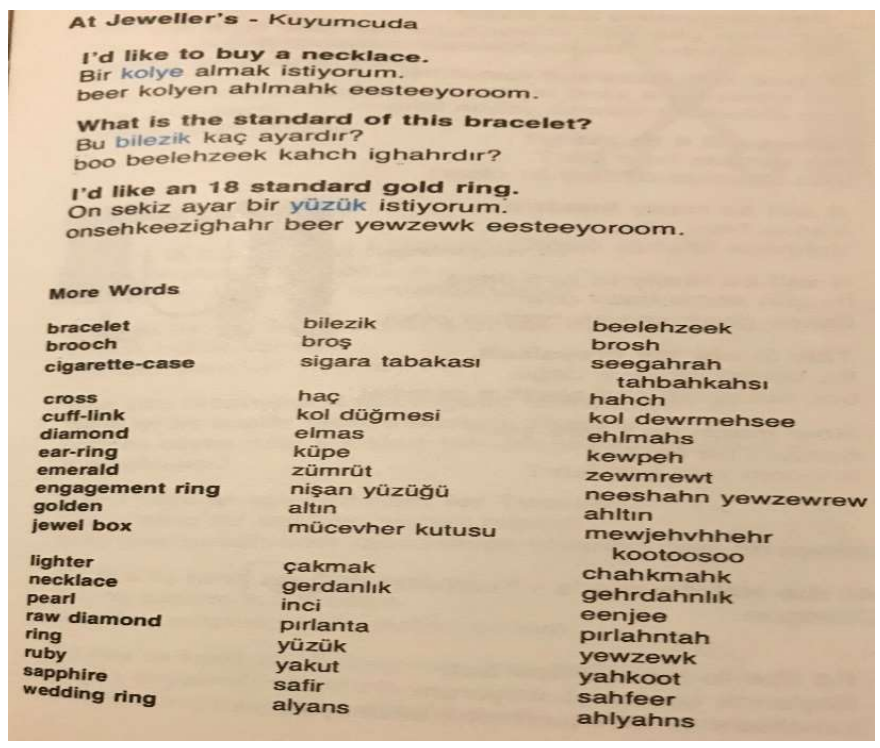

Şekil 9: Kelime, cümle ve kalıp ifadelerin telaffuzunun transkripsiyonunu gösteren görsel (Hengirmen, 1988: 93)

Get By In Turkish, gezginler ve iş adamlarına yönelik olarak Türkiye'ye yapılacak bir gezide dile bir giriş niteliğinde dil kitabı olma amacını taşıyarak tatilciler ve iş adamları için 1989 yılında ortaya çıkmıştır. Get By In Turkish adlı eser iletişimsel yaklaşıma göre yazılmıştır.

Kitapta Türkçe telaffuzun nasıl yapılması gerektiği ile önce çok kısa bir açıklama yapılmaktadır. Alfabenin 29 harften oluştuğu, 8'inin ünlü ve 21'inin ünsüz olduğu birçoğunun İngilizce eşdeğerlerine benzediği ifade edilmektedir. Kitapta Türkçenin ünlüleri, ünsüzleri İngilizce ile karşllaştırmalı olarak açlklanmakta ve ünlü uyumu hakkında bilgi verilmektedir.

Kitapta kelime, cümle ve kalıp ifadelerin seslendirilmesinin nasıl olması gerektiği ile ilgili bir bilgi bulunmamaktadır.

Kitap, iletişimsel yaklaşımla yazıldığı için diyaloglara yer verilse de diyalogların nasıl sesletileceği ile ilgili bir bilgiye rastlanmamıştır. Kitap içerisinde telaffuz öğretimine dair görsel ögelerden yararlanılmadığı tespit edilmiştir.

İncelenen bu eser, iletişimsel yaklaşıma göre yazılmış olsa da, çeviri alıştırmalarının yanında iletişimsel yaklaşıma uygun olarak etkinlik temelli iletişimsel alıştırmalar yer alsa da cevap anahtarında İngilizce okunuşuyla cümle ve diyalogların telaffuzuna yer verilmemiştir.

RumeliDE Dil ve Edebiyat Araştırmaları Dergisi Osmanağa Mahallesi, Mürver Çiçeği Sokak, No:14/8 Kadıköy - İSTANBUL / TÜRKIYE 34714 e-posta: editor@rumelide.com tel: +90 $5057958124,+902167730616$
Address

RumeliDE Journal of Language and Literature Studies

Osmanağa Mahallesi, Mürver Çiçeği Sokak, No:14/8

Kadıköy - ISTANBUL / TURKEY 34714

e-mail: editor@rumelide.com,

phone: +90 505 7958124, +90 2167730616 


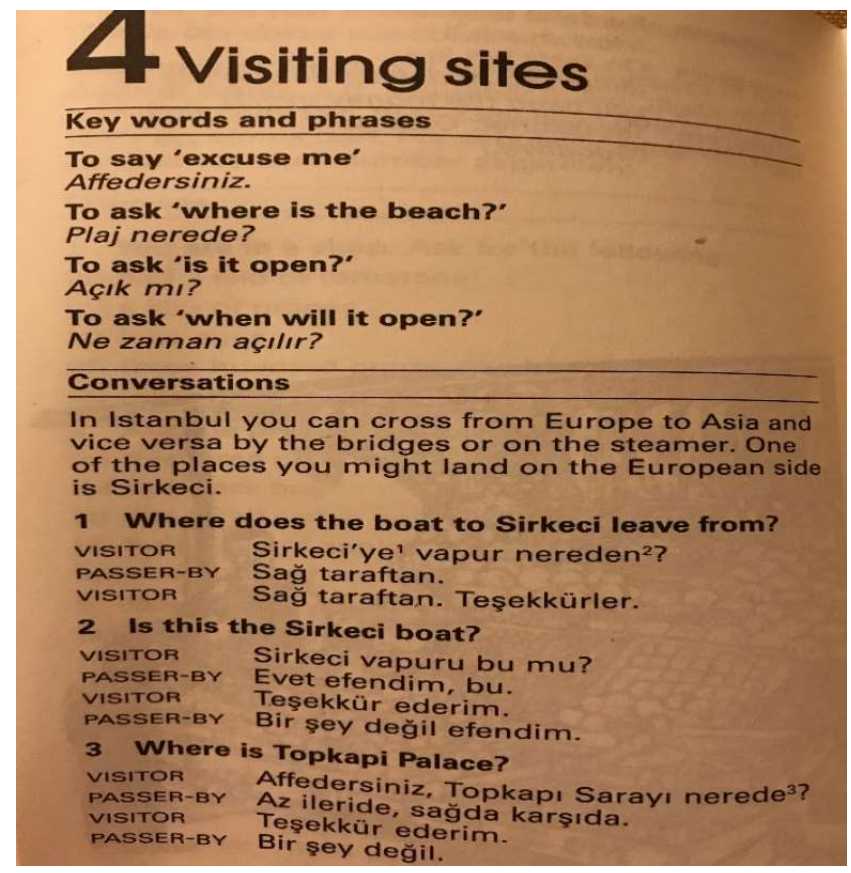

Şekil 10: Anahtar kelimeler, kalıp ifadeler ve diyalogda transkripsiyon olmayan görsel (Rona, 1989: 40)

Quick \&Easy Turkish, Türkiye'yi ziyaret edenlerin ihtiyaç duyacağ türden basit Türkçeyi anlamalarına ve konuşmalarına yardımcı olmayı amaçlayarak 1989 yılında yazılmıştır. Quick \&Easy Turkish adlı eser iletişimsel yaklaşıma göre yazılmıştır. Bu eserde Türkçe nasıl konuşulur başlı̆̆ı altında, Türk dilinin temel özellikleri verilmiştir. Türkçenin sondan eklemeli bir dil oluşu, özel işaretli harfler ve noktasız bir

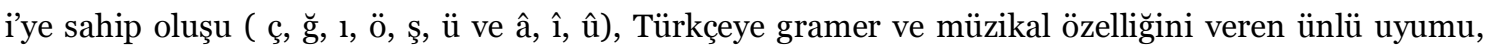
vurgunun genel olarak ilk hecede ama sorularda son heceye kaydı $\breve{g}$, ulama, $\breve{g}$ sesinin önceki sesli harfi uzatma fonksiyonuna sahip olması, Türk alfabesinde $\mathrm{Q}, \mathrm{X}$ veya $\mathrm{W}$ harflerinin olmamasına rağmen Türkler tarafından tanınmasına ve bazen ödünç alınan yabancı kelimelerde kullanılması açılanmaktadır.

Kitapta telaffuza etki eden Türkçenin özelliklerinden kısaca bahsedilse de kelime ve cümlelerin hem kitap içerisinde hem de Türkçe-İngilizce sözlükte nasıl sesletilebileceği gösterilmese de diğer kitaplardan farklı olarak hangi kelimenin hangi ünite ve alt başlı̆̆ında yer aldığı sözlük kısmında gösterilmiştir. Ayrıca kitapta telaffuz öğretiminde görsel ögelerden de yararlanılmamıştır.

RumeliDE Dil ve Edebiyat Araştırmaları Dergisi Osmană̆a Mahallesi, Mürver Çiçeği Sokak, No:14/8 Kadıköy - ISTANBUL / TÜRKIYE 34714 e-posta: editor@rumelide.com tel: +90 $5057958124,+902167730616$
Address

RumeliDE Journal of Language and Literature Studies

Osmanağa Mahallesi, Mürver Çiçeği Sokak, No:14/8

Kadıköy - ISTANBUL / TURKEY 34714

e-mail: editor@rumelide.com,

phone: +90 $5057958124,+902167730616$ 


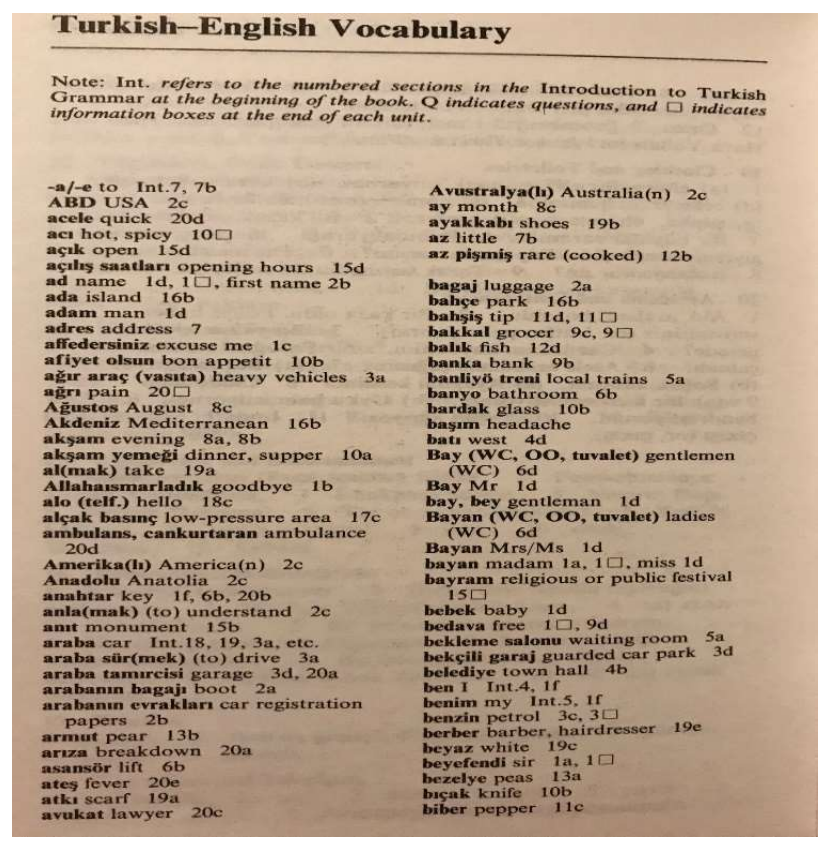

Şekil 11: Türkçe-İngilizce Sözlük (Teymur, 1989, sayfa sayısı bulunmamaktadır.)

Kitapta iletişimsel yaklaşıma uygun olarak iletişimsel odaklı, gündelik hayatın iletişim alanlarına yönelik alıştırmalar yoğun olarak tercih edilse de bunların nasıl sesletileceğini gösteren bir cevap anahtarı hazırlanmamıştır.

Turkish in Three Months, gezginlere ve iş adamlarına yönelik 1989 yllında yazılmış olup Türkçeye basit bir giriş niteliğindedir ve öncelikle kendi başına veya bir öğretmenle haftada bir veya iki saat çalışanlara yöneliktir. Turkish in Three Months adlı eserde dilbilgisi -çeviri yöntemi kullanılmıştır.

Bu kitapta da önce ünlülerin daha sonra ünsüzlerin nasıl telaffuz edilebileceği İngilizce örnekler verilerek açıklanmıştır. Daha sonra Türkçe ünlülerin uzun söylenmesi, ünlü düşmesi, ünlü uyumu, ünsüz değişmesi ve vurgu konuları açıklanmıştır. Kitap dilbilgisi-çeviri yöntemiyle yazıldığı için telaffuz alıştırmalarına yer verilmemiştir. Ayrıca kitapta giriş bölümünün dışında telaffuza ilişkin herhangi bir açıllama da bulunmamaktadır.

Kitapta dikkat çeken noktalardan biri ünlülerin telaffuzunun yer aldığı bölümde, başvurulan telaffuz kılavuzu olarak belirtilen İngilizce kelimeler, Güney İngiltere'nin Standart İngilizcesindeki gibidir.

RumeliDE Dil ve Edebiyat Araştırmaları Dergisi Osmanağa Mahallesi, Mürver Çiçeği Sokak, No:14/8 Kadıköy - İSTANBUL / TÜRKIYE 34714 e-posta: editor@rumelide.com tel: +90 505 7958124, +90 2167730616
Address

RumeliDE Journal of Language and Literature Studies

Osmanağa Mahallesi, Mürver Çiçeği Sokak, No:14/8

Kadıköy - ISTANBUL / TURKEY 34714

e-mail: editor@rumelide.com,

phone: +90 $5057958124,+902167730616$ 


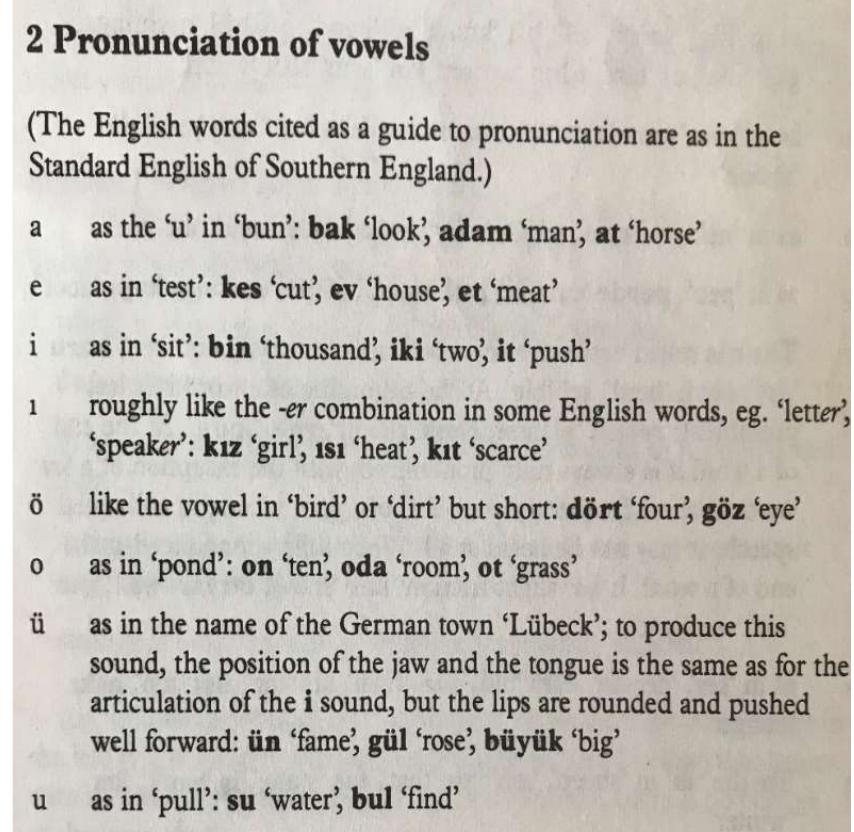

Şekil 12: Başvurulan kelimelerin Güney İngiltere'nin standart İngilizcesindeki gibi olduğunu açılayan görsel (Rona, 1989: 7)

Ayrıca kitapta kitabın yöntemine uygun olarak çeviri alıştırmalarına yer verilmiş olup, telaffuz alıştırmalarına yer verilmediği tespit edilmiştir.

Turkish in a Week, 1990 yılında gezgin ve iş adamlarına yönelik hazırlanmış olup günlük dili gezginlere öğretme amacı taşımaktadır. Turkish in a Week adlı eser iletişimsel yaklaşıma göre yazılmıştır.

Kitapta telaffuz rehberi bulunmaktadır. Telaffuz kılavuzunda iki sesli harfin yan yana gelmesiyle elde edilen bir sesli harf olarak tanımlanan diftongun Türkçede bulunmadığı, her harfin kendi sesini koruduğu, vurgunun genellikle kelimenin son hecesinde olduğu bilgisi verilmiştir. Kalın ve ince ünlülere yer verilip, ünsüzlerin İngilizcedekiyle benzer olduğu sadece c, ç, ğ, j, ş ve v seslerinin istisna olduğu ifade edilmektedir.

Kitabın içerisinde kelime ve cümlelerin telaffuzunu gösteren bölümler bulunmamakla birlikte, görsel ögelere de yer verilmemiştir. Aşă̆ıda konuşma becerisini geliştirmeye yönelik hazırlanan alıştırmanın cevap anahtarında telaffuza yönelik herhangi bir bilgi yoktur.

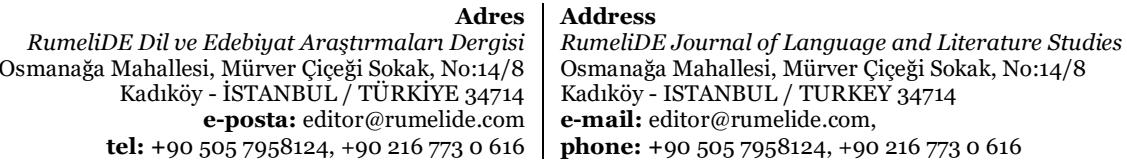




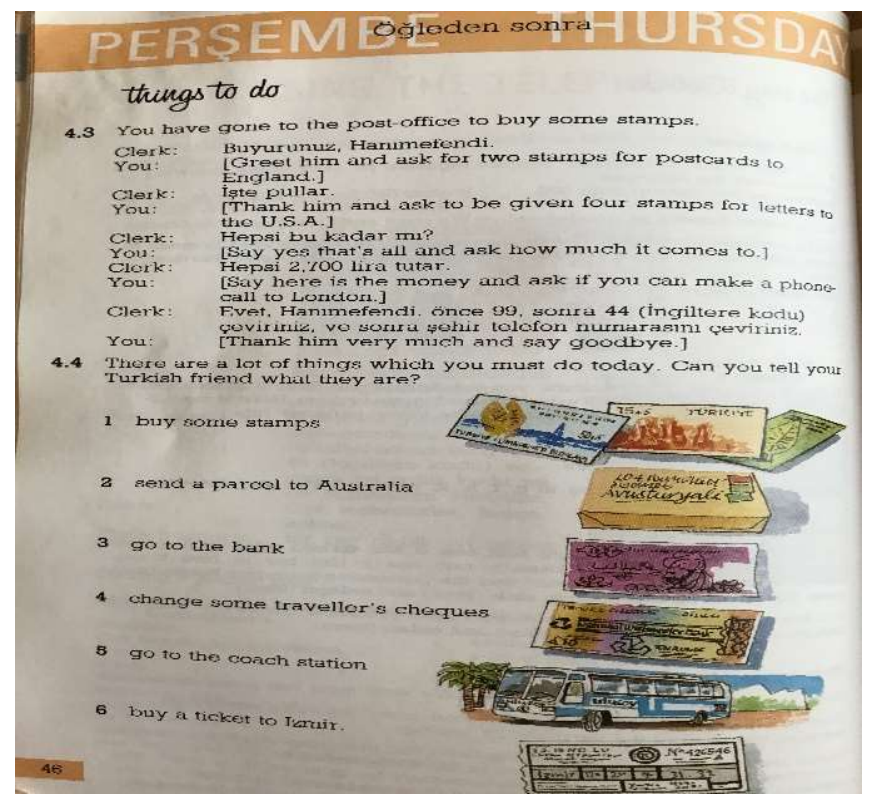

Şekil 13: Konuşma becerisine yönelik olup cevap anahtarında sesletime yer vermeyen görsel (Çağa, T. ve G. 1990: 46)

\section{Sonuç ve öneriler}

Konuşma becerisinin önemli ögelerinden sayllan hedef dilin anlaşlır telaffuz kullanımının, mesajın, gönderici ve alıcı arasında sorunsuz iletimi açısından dil öğretiminde her zaman önemi vurgulanmaktadır. Buna karşın çeşitli nedenlerle bilimsel metotlarla öğretmen tarafından öğretimi ve öğrenici tarafından öğrenilmesi ihmal edilen, kullanılan sınıf içi ders kitaplarında ise ilk seviyeden başlamak üzere ilerleyen seviyelere kadar çeşitlendirilerek oluşturulması gereken telaffuz etkinlik ve alıştırmalarının daha çok ilk seviyede toplandığı, kazanımlarda silik bir görüntü oluşturduğu tespit edilmiştir.

Sınıf içi telaffuz öğretiminde öğretmen, öğrenici ve materyal açısından birçok sorun tespit edilen alanyazından hareketle, bu çalışma kapsamında kendi kendine dil öğretimine yönelik yazılan kitaplarda telaffuz öğretiminin nasıl gerçekleştirildiği ele alınarak şu sonuçlara ulaşılmıştır.

İncelenen kitapların tümünde telaffuz rehberi bulunmaktadır. Genel olarak, hangi seslerin İngilizceden farklı olduğu, hangilerinin benzer ya da aynı sesletime sahip olduğu, nasıl sesletileceği noktasında karşılaştırmalı bir yol izlendiği tespit edilmiştir. Bu noktada ders kitaplarından ayrıldığı ve karakteristik bir özellik taşıdığı söylenebilir. Kitapların bazılarında sadece ünlüler ve ünsüzlerle ilgili bilgi verilerek yüzeysel bir tutum sergilenirken, bazılarında ayrıntılı işlenerek kitabın ilk bölümünde yer almıştır. Örneğin incelenen kitaplar arasında Turkish: A guide to the spoken language adlı eserde Türkçenin ünlü ve ünsüzleriyle doğrudan diğer kitaplarda olduğu gibi bilgi bulunmamaktadır. Kitapların tümünde sadece rehber bölümlerinde her iki dilin ses olarak farklılıkları üzerinden karşılaştırmalı olarak uyarılar yapılsa da, Turkish: A guide to the spoken language adlı eserde hem giriş bölümünde hem de kitabın içerisinde telaffuz öğretimine yönelik hem yazılı hem de görsel yolla uyarıların yapıldığı görülmektedir. Öğrenicinin yaşayabileceği olası telaffuz sorunlarından hareketle ele alınmıştır.

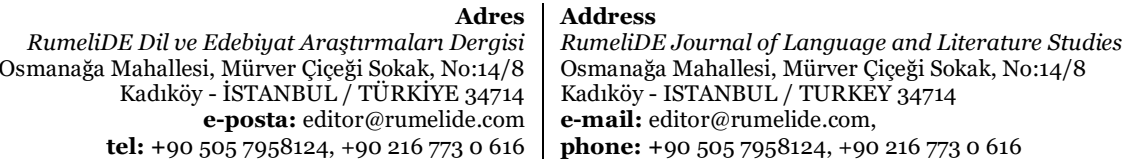


Tüm kitaplar, görsel ögelerin telaffuz öğretiminde kullanılması açısından değerlendirildiğinde görsel ögelerden yararlanılarak telaffuz öğretimine katkı sağlayan tek kitabın Turkish: A guide to the spoken language adlı kitap olduğu tespit edilmiştir.

Kitaplar, sözlük açısından değerlendirildiğinde, Modern Turkish For Beginners adlı kitapta sözlük bulunmadığı saptanmıştır. Diğer dokuz kitabın beşinde sözlük olsa da telaffuz kısmı yoktur. Dördünde ise sözlükle birlikte kelimelerin telaffuzu da verilmiştir.

Türkçenin telaffuzunda etkili olan ögelere yer verip vermeme açısından incelendiğinde, Türkçedeki vurgu sistemiyle ilgili Turkish Self-taught by Natural Method with English Phonetic Pronunciation, Qunck \&Easy Turkish, Turkish in Three Months, Turkish For Travellers (Berlitz) kitaplarında bilgi görülmektedir.

Türkçedeki hece sistemiyle ilgili Turkish Self-taught by Natural Method with English Phonetic Pronunciation, Turkish for Travellers (M. Hengirmen ),Turkish in Three Months, Turkish: A guide to the spoken language kitaplarında açıklama gözlenmektedir.

Türkçe kelimelerin yapısı ve eklerle ilgili Turkish Self-taught by Natural Method with English Phonetic Pronunciation, Quick \&Easy Turkish, Turkish for Travellers (M. Hengirmen, Turkish in Three Months, Turkish For Travellers (Berlitz) kitaplarında bilgi bulunmaktadır.

İngilizcede olmayan seslerle ilgili, Turkish Self-taught by Natural Method with English Phonetic Pronunciation, Turkish in Three Months kitaplarında açıllamalar tespit edilmektedir.

Ünsüz benzeşmesiyle ilgili, Turkish Self-taught by Natural Method with English Phonetic Pronunciation, Turkish for Travellers (M. Hengirmen ) Turkish in Three Months, Modern Turkish For Beginners adlı kitaplarda bilgi olup diğerlerinde yoktur. Ünlü uyumuyla ilgili Turkish: A guide to the spoken language dışında bütün kitaplarda bilgi vardır.

Yöntem ve yaklaşımlara göre değerlendirildiğinde telaffuz öğretiminin en etkili olduğu kitap işitseldilsel yöntemle yazılan Turkish: A guide to the spoken language adlı kitaptır. Dilbilgisi-çeviri yönteminin kullanıldığı bir kitapta telaffuza yer verilmezken diğerinde yer verildiği, aynı şekilde iletişimsel yaklaşımın hâkim olduğu kitaplardan birinde telaffuzun yer aldığı diğerinde yer almadığı görülmektedir. Yöntem ve yaklaşımların uygulanışında da sorun bulunmakla birlikte bu durum ders kitaplarında tercih edilen yöntem ve yaklaşımlardan bağımsız olarak değerlendirilmesi gereken kendi kendine dil öğrenme kitaplarının özerk yapısı düşünülerek bazı çıkarma ve eklemelerin de yapılabileceğini göstermektedir.

Ayrıca kitaplarda verilen teorik bilginin alıştırma, etkinliklerle öğrenici de test edilmediği, kitaplarda telaffuz öğretiminin ölçme ve değerlendirme kısmının eksik bırakıldı̆̆ı tespit edilmiştir.

Bu tür kitapların ders kitaplarından, öğreticinin yokluğu göz önünde bulundurularak farklı olduğu düşünüldüğünde şunlar önerilebilir.

Türkçeyi hiç bilmeyen öğreniciler oldukları düşünüldüğünde Türkçenin telaffuzuna giriş niteliğinde, kitabın giriş kısmında bir rehber bulunmalı ve bu rehberde Türkçenin telaffuzuna etki eden karakteristik özellikler sıralanmalıdır.

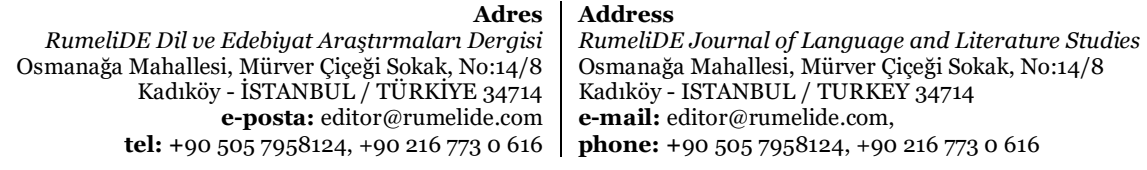


Bu tür kitaplar, ders kitaplarından farklı olarak iki dilli olarak yazılan kitaplar olduğu için Türkçenin telaffuzunda doğrudan etkili olan ögeler olan ünlü, ünsüzlere diğer dille karşılaştırmalı olarak yer verilmelidir. Karşılaştırmada, her iki dildeki benzer seslerin telaffuz farklılıkları varsa verilmeli, bir dilde olmayıp diğer dilde olan sesler ve nasıl telaffuz edildiği öğrenicinin ana dilinden hareketle gösterilmelidir.

Türkçenin karakteristik özelliklerinden olan ünlü, ünsüz uyumuyla ilgili bilgi verilerek, Türkçenin sesletiminde nasıl etkili olduğu örneklerle açıklanarak, dinle ve tekrar et, sesli okuma alıştırmalarında ses kayıtlarından takip edebilecekleri şekilde aktarılmalıdır.

Türkçedeki vurgu sistemi de görsellerden yola çlkılarak, vurgulu söylenecek hecenin seslerinin büyük yazılarak bir görsel içerisinde verilmesiyle bu duruma dikkat çekilebilir.

Bir diğer eksiklik ise telaffuz etkinlik ve alıştırmalarının yokluğudur. Bu etkinlik ve alıştırmalara yer verilmekle kalmayıp aynı zamanda öğrenicinin kendisini ölçüp değerlendirilebileceği, ünite sonu değerlendirme testleri cevap anahtarıyla birlikte yer almalı ve öz değerlendirmeye de yer verilmelidir.

Sayllabilecek eksikliklerden biri de sözlük ya da kelime listesi verilse de kelimelerin nasıl sesletileceğinin gösterilmemesidir. Hedef kitlenin ana dili ya da bildiği dil temel alınarak tüm kelime ve ifadelerin o dildeki okunuşunu gösteren bir yazımla yazılması önerilmektedir.

Sadece kelimelerin değil, aynı zamanda kalıp ifade, cümle ve diyalogların da konuşma becerisi ağırlıklı kitaplarda telaffuz öğretilmesine yönelik telaffuzlarıyla yer alması etkili bir fayda üretecektir.

Bu açıdan telaffuzun ve uygulanışının kendi kendine Türkçe öğrenme kitaplarında nasıl ve ne kadar yer alması gerektiğinin belirlenmesi, bu doğrultuda bir plan hazırlanması ve uygulanması gerekmektedir.

\section{Kaynakça}

Aksan, D. (1975). Ana dili. Türk Dili, 285 (31), 423-434.

Aksan, D. (1999). Türkçenin gücü (4.bs.). Ankara: Bilgi.

Alyılmaz, C. (2010). Türkçe öğretiminin sorunları. Turkish Studies International Periodical for the Languages, Literature and History of Turkish or Turkic, 5 (3), 728-749.

Aslan, E. (2015). Dil alanlarının öğretimi, dilbilgisi, sözcük, telaffuz, çeviri öğretimi. A. Sarıçoban (Ed.). Yabancı Dil Olarak Türkçe Ö̆gretim Metodolojisi içinde (s. 94-108). Ankara: Anı.

Başkan, Ö. (2006). Yabancı dil öğretimi ilkeler ve çözümler. İstanbul: Multilingual.

Bodorik M. (2017). Teaching English pronunciation by non-native teachers as seen by Slovak teachers. Journal of Language and Cultural Education, 5 (3), 157-174.

Bölükbaş, F. (2018). İşitsel-dilsel yöntem (Audio-lingual method). M. Durmuş ve A. Okur (Ed.), Yabancılara Türkçe Öğretimi El Kitabı içinde (s. 61-66). (2.bs.) İstanbul: Grafiker.

Çağa, T. ve G. (1990). Turkish in a week. Great Britain: Headway.

Çakır H. (2015). Öğretmen adaylarının sözlü anlatım öz yeterlik inançlarının değerlendirilmesi. (Yayımlanmamış yüksek lisans tezi), Dokuz Eylül Üniversitesi Eğitim Bilimleri Enstitüsü, İzmir.

Demir, A. (2013). Yabancı dil eğitiminde temel dil becerileri. Y. Şahin (Ed.). Farklı Boyutlarıyla Yabancı Dil Öğrenimi ve Öğretimi kitabı içinde (s.117-130). Konya: Eğitim.

Demirel, Ö. (2012). Yabancı dil öğretimi. Ankara: Pegem Akademi.

Editions Berlitz S.A. (1975). Turkish for travellers. Belgium.

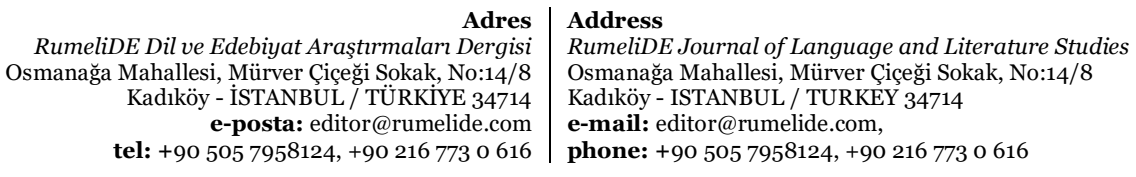


Ergenç, İ. (1989), Dilimizdeki ünsüz yığılmaları üzerine bir deneme, Ortak Kitap'89 (1), 248-285, Ankara.

Ergenç, İ. (2002). Spoken language and dictionary of turkish articulation. İstanbul: Multilingual.

Ermağan, E. (2021a). II. Dünya Savaşı esnasında Amerikan askerlerine Türkçe öğretmek için yazılan "Turkish: A Guide To The Spoken Language" adlı kitabın dil öğretimi açısından değerlendirilmesi. RumeliDE Dilve Edebiyat Araştırmaları Dergisi, (Ö9), 43-55. DOI: 10.2900o/rumelide.983856.

Ermağan, E. (2021b). Alanya örneğinde Almanca-Türkçe iki dillilik: ses, yapı ve anlambilim açısından toplumdilbilimsel bir inceleme. (Yayımlanmamış doktora tezi), Hacettepe Üniversitesi Türkiyat Araştırmaları Enstitüsü, Ankara.

Hengirmen, M. (1988). Turkish for travellers. Ankara: Engin.

Karaca A. (2019). 6. Sinıf öğrencilerinin konuşmalarında karşılaşılan söyleyiş ve boğumlama yanlsşları. (Yayımlanmamış yüksek lisans tezi), Ordu Üniversitesi Sosyal Bilimler Enstitüsü, Ordu.

Keser, S. (2018). Yabancı dil olarak Türkçe öğretiminde konuşma becerisinin geliştirilmesinde karşlaşılan güçlükler. (Yayımlanmamış Yüksek Lisans Tezi), Hacettepe Üniversitesi Türkiyat Araştırmaları Enstitüsü, Ankara.

Köroğlu, S. A. (2015). Literatür taraması üzerine notlar ve bir tarama tekniği, GIDDB Dergi, 1, 61-69.

Mandil, D. (1977). Turkish made easy. İstanbul: Öğretim.

Memiş, M. R. ve Erdem, M. D. (2013). Yabancı dil öğretimde kullanılan yöntemler, kullanım özellikleri ve eleştiriler. Turkish Studies-International Periodical For The Languages, Literature and History of Turkish or Turkic. 8 (9), 297-318.

Mughul, Y.M. (1979). Modern Turkish for beginners. İstanbul: İstanbul Matbaası.

Onan, B. (2014). Anlama sürecinde Türkçenin yapısal işlevleri. (2. bs.). Ankara: Nobel Akademik.

Özbal, B. (2020). Kendi kendine yabancı dil olarak Türkçe öğrenimi ders kitapları. Uluslararası Türkçe Edebiyat Kültür Ĕ̆itim Dergisi, 9 (4), 1602-1615.

Özgür İ. (2006.) Konuşma bozukluğu ve sağaltımı. Ankara: Nobel.

Potur, Ö. ve Yıldız, N. (2016). Konuşma becerisi alanında yapılan akademik çalışmaların eğilimleri, Dil ve Edebiyat Eğitimi Dergisi, 27-40.

Rona, B. (1989). Get by in Turkish. England: Belmont Press.

Rona, B. (1989). Turkish in three months. Great Britain: Hugo's Language Books.

Şenel, M. (2006). Suggestions for beautifying the pronunciation of efl learners in Turkey. Journal of Language and Linguistic Studies, 2 (1), 111-125.

https://www.jlls.org/index.php/jlls/article/view/27/29 adresinden erişildi.

Şenyiğit Y. ve Okur A. (2019). Yabancllara Türkçe öğretiminde konuşma becerisi ve telaffuz eğitimi. Mehmet Akif Ersoy Üniversitesi Ĕ̆itim Fakültesi Dergisi, (52), 519-549.

Tanrı̈ğen, A. (2009). Bilimsel araştırma yöntemleri. Ankara: Anı.

Tecim M. E. (2017). Wals info veri tabanına göre Almanca, Fransızca ve Türkçenin karşılaştırılması. (Yayımlanmamış yüksek lisans tezi). Ankara Üniversitesi Sosyal Bilimler Enstitüsü, Ankara.

TDK. https://sozluk.gov.tr/?kelime=bo\%C4\%9Fumlanma, 23.9.2021 tarihinde erişildi.

Teymur N. (1989). Quick \&easy Turkish. Great Britain: Headway.

Toraman Ünal, E. (2020). Türkçenin yabancı dil olarak öğretiminde ders kitaplarında kullanılan telaffuz yöntem ve uygulamalar üzerine bir inceleme. (Yayımlanmamış yüksek lisans tezi). Nevşehir Hacı Bektaşi Veli Üniversitesi Sosyal Bilimler Enstitüsü, Nevşehir.

War Department (1943). Turkish: A guide to the spoken language. Washington.

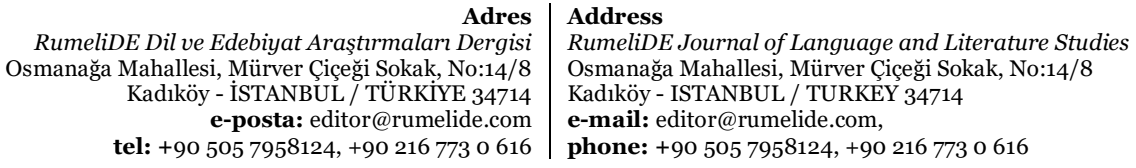


Yıldırım, A. ve Şimşek, H. (2008). Sosyal bilimlerde nitel araştırma yöntemleri. (7. bs.). Ankara: Seçkin. 